\title{
Age-related changes in synaptic markers and monocyte subsets link the cognitive decline of APP swe $_{\text {PS1 mice }}$
}

\section{Gaëlle Naert and Serge Rivest*}

Laboratory of Endocrinology and Genomics, CHUQ Research Center and Department of Molecular Medicine, Faculty of Medicine, Laval University, Québec City, QC, Canada

\section{Edited by:}

Shawn Hayley, Carleton University, Canada

\section{Reviewed by:}

Rafael Linden, Federal University of Rio de Janeiro, Brazil

Takumi Takizawa, Gunma University, Japan

\section{${ }^{*}$ Correspondence:}

Serge Rivest, Laboratory of Endocrinology and Genomics, CHUQ Research Center and Department of Molecular Medicine, Faculty of Medicine, Laval University, 2705 Laurier boul., Québec City, QC G1V 4G2, Canada. e-mail: serge.rivest@crchul.ulaval.ca
Alzheimer's disease (AD) is characterized by a progressive memory decline and numerous pathological abnormalities, including amyloid $\beta(A \beta)$ accumulation in the brain and synaptic dysfunction. Here we wanted to study whether these brain changes were associated with alteration in the population of monocyte subsets since accumulating evidence supports the concept that the innate immune system plays a role in the etiology of this disease. We then determined the immune profile together with expression of genes

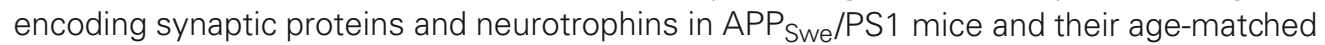
wild-type (WT) littermates. We found that the progressive cognitive decline and the dramatic decrease in the expression of numerous synaptic markers and neurotrophins correlated with a major defect in the subset of circulating inflammatory monocytes. Indeed the number of $\mathrm{CX}_{3} \mathrm{CR} 1^{\text {low }}{ }_{\mathrm{Ly}} 6-\mathrm{C}^{\text {high }} \mathrm{CCR}_{2}{ }^{+} \mathrm{Gr}_{1}{ }^{+}$monocytes remained essentially

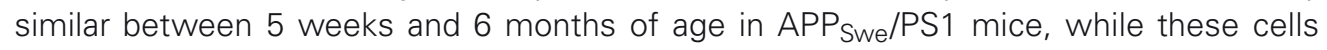
significantly increased in 6-month-old WT littermates. Of great interest is that the onset of cognitive decline was closely associated with the accumulation of soluble $A \beta$, disruption of synaptic activity, alteration in the BDNF system, and a defective production in the subset of $\mathrm{CX}_{3} \mathrm{CR} 1^{\text {low }}{ }_{\mathrm{Ly} 6}$-C ${ }^{\text {high }} \mathrm{CCR} 2{ }^{+} \mathrm{Gr}_{1}{ }^{+}$monocytes. However, these memory impairments can be prevented or restored by boosting the monocytic production, using a short treatment of macrophage colony-stimulating factor (M-CSF). In conclusion, low CCR2 ${ }^{+}$monocyte production by the hematopoietic system may be a direct biomarker of the cognitive decline in a context of $A D$.

Keywords: Alzheimer's disease, bone marrow-derived microglia, monocytes, CCR2, BDNF, memory impairments

\section{INTRODUCTION}

Alzheimer's disease $(\mathrm{AD})$ is a progressive neurodegenerative disorder affecting the elderly. $\mathrm{AD}$ begins as mild short-term memory deficits and culminates in total loss cognition and executive functions. The two core pathological hallmarks are amyloid deposits and neurofibrillary tangles (Selkoe, 2002). These senile plaques appeared primarily in the cerebral cortex and hippocampus, leaving the brainstem and cerebellum essentially unaffected. Amyloid precursor protein (APP) is cleaved to produce beta-amyloid (A $\beta$ ) peptides, namely $A \beta_{1-40}$ and $A \beta_{1-42}$. $A \beta$ oligomerizes to form $A \beta$ oligomers, small aggregates of $2-12$ peptides, and then aggregates to form pro-fibrils and fibrils to generate the $A \beta$ plaque (Lesné et al., 2006; Haass and Selkoe, 2007). Although $A \beta$ deposits were for a long time thought to induce mnesic impairments, the correlation between parenchymal amyloid deposition and cognitive decline still remains controversial. Indeed, plaque density and $A \beta$ load do not necessarily correspond to the degree of dementia. Accumulating evidence supports a detrimental role of soluble $A \beta$ in the brains of both AD patients (Lue et al., 1999; McLean et al., 1999) and mouse models of AD (Lesné et al., 2006, 2008; Cheng et al., 2007). Such intraneuronal and extracellular accumulation of soluble $\mathrm{A} \beta$ oligomers may cause neuronal dysfunctions much before than neurodegeneration (Haass and Selkoe, 2007).
It is believed that $\mathrm{AD}$ begins with subtle alterations in the hippocampal synaptic activity prior to frank neuronal degeneration (Selkoe, 2002). Soluble $A \beta$ may affect synaptic functions since it abrogates synaptic plasticity and induces memory impairments (Ma and Klann, 2011) and interferes with normal activity and trafficking of several synaptic receptors ( $\mathrm{Ma}$ and Klann, 2011). Moreover $A \beta$ is able to modify the expression of genes critical for learning and memory or neuroprotection in hippocampus (Dickey et al., 2003).

In human and mouse $\mathrm{AD}$ brain, microglia are associated with cerebral amyloid deposits (Dickson et al., 1988; Haga et al., 1989; Malm et al., 2005; Stalder et al., 2005; Simard et al., 2006). Microglia, the mononuclear phagocyte of the brain (Perry and Gordon, 1988), react to $\mathrm{A} \beta$ and have the ability to phagocytose it (Bolmont et al., 2008; Boissonneault et al., 2009; Mandrekar et al., 2009; Lee et al., 2010; Liu et al., 2010). However, the progressive $\mathrm{A} \beta$ accumulation together with the activation and recruitment of microglia toward plaque formation suggests that the ability of microglia to clear $\mathrm{A} \beta$ decreases with age and during $\mathrm{AD}$ progression (Hickman et al., 2008). Recent studies demonstrate that several subsets of microglia exist and can have different roles and properties (Naert and Rivest, 2011b). Microglia are replenished by division of resident cells and by recruitment of peripheral 
monocytes during neuropathological conditions (Simard and Rivest, 2004; Simard et al., 2006; Soulet and Rivest, 2008). Immunocompetent bone marrow-derived microglia (BMDM) have been shown to restrict amyloid pathology and prevent the cognitive decline in mouse models of $\mathrm{AD}$ (Simard and Rivest, 2006; Town et al., 2008; Mildner et al., 2011; Naert and Rivest, 2012). These data support the concept that microglia precursor recruitment from circulating monocytes is a natural protective mechanism against $A \beta$ accumulation and cognitive decline.

Monocytes population is divided into three subsets in human and two subsets in mice, namely inflammatory subset $\mathrm{CX}_{3} \mathrm{CR}_{1}{ }^{\text {low }} \mathrm{Ly} 6-\mathrm{C}^{\text {high }} \mathrm{Gr} 1^{+} \mathrm{CCR} 2^{+}$and the patrolling monocyte $\mathrm{CX}_{3} \mathrm{CR}^{\text {high }}{ }^{\text {Ly6-C }} \mathrm{C}^{\text {low }} \mathrm{Gr} 1^{-} \mathrm{CCR} 2^{-}$(Geissmann et al., 2003; Auffray et al., 2009). Both subsets might be able of infiltrating in inflamed brain, with predominantly Ly6-C ${ }^{\text {high }}$ cells (Saederup et al., 2010). However, $\mathrm{CX}_{3} \mathrm{CR} 1^{\text {low }} \mathrm{Ly} 6-\mathrm{C}^{\text {high }} \mathrm{Gr} 1^{+} \mathrm{CCR} 2^{+}$subset is believed to be largely responsible of the blood-derived microglia during pathological conditions (Mildner et al., 2007; Getts et al., 2008; Naert and Rivest, 2012). The chemokine CCL2 is the main CCR2 ligand and is upregulated in brains of $\mathrm{AD}$ patients and mouse models of AD (Ishizuka et al., 1997; Grammas and Ovase, 2001; Simard et al., 2006; El Khoury et al., 2007; Naert and Rivest, 2011a), suggesting the preferential recruitment of CCR2 ${ }^{+}$monocytes. Recently we have shown that CCR2 deficiency in $\mathrm{APP}_{\text {Swe }} / \mathrm{PS} 1$ mice aggravated mnesic impairments and enhanced $A \beta$ pathology (Naert and Rivest, 2011a). In addition, CCR2 deficiency specifically in bone marrow cells also enhanced $\mathrm{AD}$ physiopathology in $\mathrm{APP}_{\text {Swe }} / \mathrm{PS} 1$ mice (Mildner et al., 2011; Naert and Rivest, 2012) and these effects were prevented by the transplantation of competent CCR2 hematopoietic stem cells (Naert and Rivest, 2012). Of great interest are the data that CCR2 gene delivery in bone marrow cells rescued memory impairments of non-irradiated $\mathrm{APP}_{\text {Swe }} / \mathrm{PS} 1$ mice, suggesting a defect in the CCR2 system during AD (Naert and Rivest, 2012). These data underline the possibility that hematopoietic system is defective in AD subjects and in a context of APP gene overexpression.

The aim of this study was therefore to compare the immune profile together with synaptic dysfunction and soluble $A \beta$ accumulation in $\mathrm{APP}_{\text {Swe }} / \mathrm{PS} 1$ mice before and after the onset of mnesic impairments. We took advantage of this mouse model since each mother delivery generates around 50\% double transgenic and 50\% wild-type (WT) allowing a perfect match between $\mathrm{APP}_{\text {Swe }} / \mathrm{PS} 1$ mice and WT littermates of the same gender. We used only male for this study to avoid the possible influence of the ovulatory cycle and variations in circulating levels of sex steroids on the immune system. Compared to their WT littermates 6-month-old $\mathrm{APP}_{\mathrm{Swe}} / \mathrm{PS} 1$ mice exhibit a clear defect in the production inflammatory monocytes and this correlates with mnesic impairments, reduction in synaptic markers, and accumulation of soluble $A \beta$.

\section{MATERIALS AND METHODS ANIMALS}

We used adult male C57BL/6 mice (WT), CCR2-/- (B6.129S4Ccr2tm1Ifc/J) and APP transgenic mice $\left(\mathrm{APP}_{\text {Swe }} / \mathrm{PS} 1\right)$ harboring the chimeric mouse/human $\beta$-amyloid precursor protein
(APP695swe) and the human presenilin I (A246E variant) under the control of independent mouse prion protein promoter elements [B6C3-Tg(APP695)3Dbo Tg(PSEN1)5Dbo/J]. All the mice were originally purchased from the Jackson Laboratory and maintained in a pure $\mathrm{C} 57 \mathrm{BL} / 6 \mathrm{~J}$ background. $\mathrm{APP}_{\text {Swe }} / \mathrm{PS} 1$ were bred with the $C C R 2^{-/-}$mouse strain for $\geq 3$ generations to generate $\mathrm{APP}_{\text {Swe }} / \mathrm{PS} 1 / \mathrm{CCR} 2^{-/-}$triple transgenic animals. All newborn pups were genotyped as described previously (Simard and Rivest, 2006) and double transgenic and WT littermates were maintained in the same environment Mice were housed 3-5 per cage and acclimated to standard laboratory conditions (12-h light, 12-h dark cycle; lights on at 07:00 and off at 19:00) with free access to mouse chow and water. Animal breeding and experiments were conducted according to Canadian Council on Animal Care guidelines, as administered by the Laval University Animal Care Committee.

\section{BEHAVIORAL ANALYSES: WATER T-MAZE}

Mice were tested during the "light-on" phase of the day. Behavioral experimenter was blind to the genetic and treatment status of animals. To assess hippocampal-dependent spatial learning and memory, mice were trained in the water T-maze task. In this paradigm, we evaluate the mouse's ability to remember the spatial location of submerged platform. The T-maze apparatus (stem length, $64 \mathrm{~cm}$; arms length, $30 \mathrm{~cm}$; width, $12 \mathrm{~cm}$; wall height, $16 \mathrm{~cm}$ ) was made of clear fiberglass and filled with water $\left(23 \pm 1^{\circ} \mathrm{C}\right)$ at a height of $12 \mathrm{~cm}$. A platform $(11 \times 11 \mathrm{~cm})$ was placed at the end of the target arm and was submerged $1 \mathrm{~cm}$ below the surface. The acquisition phase allows to evaluate animals for left-right spatial learning. During the first two trials, platforms were placed on each arm of the maze to test the spontaneous turning preference of the mouse. After these two trials, the least chosen arm was reinforced by the escape platform. The mice were placed in the stem of the T-maze and were left to choose swimming either left or right until they found the submerged platform and escaped to it for a maximum of $60 \mathrm{~s}$. After reaching the platform, the mice remained on it for $20 \mathrm{~s}$ and were then immediately placed back into the maze. If the animals did not find the platform within this limit, they were gently guided onto it. Repeated trials were presented on the same day up to a maximum of 48 trials. A rest period of at least $10-15$ min intervened between each block of 10 trials. A mouse was considered to have learned the task when it made no errors in a block of five consecutive trials. The reversal learning phase was then conducted $48 \mathrm{~h}$ later. During this phase, the same protocol was repeated, except that mice were trained to find the escape platform on the side opposite to where they had learned in the acquisition phase. The number of trials to reach the criterion (5/5 correct choices made on consecutive trials) was measured as well as the latency to find the escape platform.

\section{TISSUE ANALYSES}

Mice were anesthetized under isofluorane. For first group of mice used for behavioral analysis, brains were rapidly removed from the skulls and placed for 2-4 days in 4\% paraformaldehyde (PFA), $\mathrm{pH} 9.5$ at $4^{\circ} \mathrm{C}$, and then placed in a PFA solution containing $10 \%(\mathrm{w} / \mathrm{v})$ sucrose overnight at $4^{\circ} \mathrm{C}$. The frozen brains were 
mounted on a microtome (Reichert-Jung) and cut into $25-\mu \mathrm{m}$ coronal sections. The slices were collected in cold cryoprotectant solution $(0.05 \mathrm{M}$ sodium phosphate buffer, $\mathrm{pH} 7.3,30 \%$ ethylene glycol, and $20 \%$ glycerol) and stored at $-20^{\circ} \mathrm{C}$ until performing immunocytochemistry or in situ hybridization histochemistry. A second group of mice was used for hippocampus analysis. Hippocampus were rapidly removed from the brain, frozen in liquid nitrogen, and stored at $-80^{\circ} \mathrm{C}$ for RNA and protein analysis.

\section{In situ hybridization and immunohistochemistry}

Every 12th section of brain slices, starting from the end of the olfactory bulb to the end of the cerebral cortex, was mounted on Colorfrost/Plus microscope slides (Fisher Scientific) for WT and $\mathrm{APP}_{\text {Swe }} / \mathrm{PS} 1$ mice, from 3 to 12 months of age, ( $n=5-12$ per group). In situ hybridization for the histochemical localization of brain-derived neurotrophic factor (BDNF), early-growth response protein 1 (Egr1), activityregulated cytoskeleton-associated gene (Arc), two subunits of the $\mathrm{N}$-methyl-D-aspartate-type (NMDA) glutamate receptor, NR2A and NR2B, was performed using ${ }^{35}$ S-labeled cRNA probes. Plasmids were linearized, sense and antisense cRNA probes were synthesized with the appropriate RNA polymerase, as described in Table 1. Riboprobe synthesis and preparation and in situ hybridization were performed according to a previously described protocol (Laflamme et al., 1999; Laflamme and Rivest, 2001; Nadeau and Rivest, 2000; Naert et al., 2009).

All images were captured using a Nikon Eclipse 80i microscope equipped with a digital camera (QImaging), processed to enhance contrast and sharpness using Adobe Photoshop 7 (Adobe Systems), and then assembled using Adobe Illustrator (Adobe Systems). The images depicted by the different panels are representative of the signal detected on the slides for each group of mice.

\section{Stereological analysis}

An observer who was blind to the treatment status of the material did all quantitative histological analyses. To count

Table 1 | Plasmids and enzymes used for the synthesis of the cRNA probes.

\begin{tabular}{|c|c|c|c|c|c|}
\hline Plasmid & Vector & Insert & $\begin{array}{l}\text { Antisense } \\
\text { probe }\end{array}$ & $\begin{array}{l}\text { Sense } \\
\text { probe }\end{array}$ & Source \\
\hline $\begin{array}{l}\text { Mouse } \\
\text { Arc }\end{array}$ & $\begin{array}{l}\text { PCR II } \\
\text { Topo }\end{array}$ & $869 \mathrm{bp}$ & EcoR I/Sp6 & $\begin{array}{l}\text { Hind } \\
\text { III/T7 }\end{array}$ & Cloned by PCR \\
\hline $\begin{array}{l}\text { Mouse } \\
\text { BDNF }\end{array}$ & $\begin{array}{l}\text { PCR II } \\
\text { Topo }\end{array}$ & $342 \mathrm{bp}$ & Xho I/Sp6 & $\begin{array}{l}\mathrm{BamH} \\
I / T 7\end{array}$ & $\begin{array}{l}\text { Dr. D. Levesque, } \\
\text { Laval University, } \\
\text { Québec, QC, Canada }\end{array}$ \\
\hline $\begin{array}{l}\text { Mouse } \\
\text { EGR1 }\end{array}$ & $\begin{array}{l}\text { PCR II } \\
\text { Topo }\end{array}$ & $965 \mathrm{bp}$ & Xba I/Sp6 & $\begin{array}{l}\mathrm{BamH} \\
\mathrm{I} / \mathrm{TT}\end{array}$ & Cloned by PCR \\
\hline $\begin{array}{l}\text { Mouse } \\
\text { NR2A }\end{array}$ & $\begin{array}{l}\text { PCR II } \\
\text { Topo }\end{array}$ & 1017 bp & BamH I/SP6 & $\begin{array}{l}\text { Xho } \\
\text { I/T7 }\end{array}$ & Cloned by PCR \\
\hline $\begin{array}{l}\text { Mouse } \\
\text { NR2B }\end{array}$ & $\begin{array}{l}\text { PCR II } \\
\text { Topo }\end{array}$ & $755 \mathrm{bp}$ & $\mathrm{BamH}$ I/T7 & $\begin{array}{l}\text { Xba } \\
\text { I/Sp6 }\end{array}$ & Cloned by PCR \\
\hline
\end{tabular}

$\mathrm{A} \beta$ plaques, sections of 3- and 6-month-old $\mathrm{APP}_{\text {Swe }} / \mathrm{PS} 1$ mice ( $n=6-15$ per group) were immunostained for $\mathrm{A} \beta$ protein (polyclonal mouse anti-A $\beta$ 6E10; Covariance) with $4^{\prime}, 6^{\prime}$-diamidino-2phenylindole, as previously reported (Simard et al., 2006; Richard et al., 2008). Four sections were chosen for hippocampus at $-1.70,-1.94,-2.46$, and $-2.92 \mathrm{~mm}$ from the bregma according to a stereotaxic atlas (Paxinos and Franklin, 2nd edition). Unbiased stereological analysis was performed as described previously (Simard et al., 2006; Richard et al., 2008; Boissonneault et al., 2009). Briefly, the contours of the hippocampus areas were traced as virtual overlays on the steamed images and areas were calculated. The area occupied by all $A \beta$-labeled plaques was determined as previously described (Naert and Rivest, 2011a).

\section{Protein and RNA extraction}

Proteins from hippocampus of 3- and 6-month-old WT and $\mathrm{APP}_{\text {Swe }} / \mathrm{PS} 1$ mice were extracted using a modified version of the procedure published by Lesné et al. (2006). All manipulations were done on ice to minimize protein degradation. One hippocampus was placed in a 1-ml syringe with a $20 \mathrm{G}$ needle. $250 \mu \mathrm{l}$ of buffer A (50 mM Tris- $\mathrm{HCl}$ pH 7.6, 0.01\% NP-40, $150 \mathrm{mM} \mathrm{NaCl}, 2 \mathrm{mM}$ EDTA, $0.1 \%$ SDS, $1 \mathrm{mM}$ phenylmethylsulfonyl fluoride (PMSF), protease inhibitor cocktail) were added and 10-up-and-down strokes were made to homogenize the tissue. The mixture was then separated in two tubes one for protein extraction and the other for RNA extraction.

The tube for protein was centrifuged for $5 \mathrm{~min}$ at $3000 \mathrm{rpm}$ at $4^{\circ} \mathrm{C}$. The supernatant (extracellular proteins enriched fraction) was collected and frozen at $-80^{\circ} \mathrm{C}$. The insoluble pellet was suspended in $250 \mu \mathrm{l}$ TNT-buffer (Buffer B; $50 \mathrm{mM}$ Tris$\mathrm{HCl} \mathrm{pH}$ 7.6, $150 \mathrm{mM} \mathrm{NaCl}, 0.1 \%$ Triton X-100, 1 mM PMSF, protease inhibitor cocktail), followed by a 90 min centrifugation at $13,000 \mathrm{rpm}$ at $4^{\circ} \mathrm{C}$. The supernatant (cytoplasmic proteins enriched fraction) was then collected and frozen at $-80^{\circ} \mathrm{C}$. The pellet was suspended in $250 \mu \mathrm{l}$ buffer $\mathrm{C}$ ( $50 \mathrm{mM}$ Tris- $\mathrm{HCl} \mathrm{pH} 7.4$, $150 \mathrm{mM} \mathrm{NaCl}, 0.5 \%$ Triton X-100, $1 \mathrm{mM}$ EGTA, 3\% SDS, 1\% deoxycholate, $1 \mathrm{mM}$ PMSF, protease inhibitor cocktail) and incubated at $4^{\circ} \mathrm{C}, 50 \mathrm{rpm}$, for $1 \mathrm{~h}$. The samples were centrifuged for $90 \mathrm{~min}$ at $13,000 \mathrm{rpm}$ and $4^{\circ} \mathrm{C}$ and the supernatant (membrane proteins enriched fraction) was collected and frozen at $-80^{\circ} \mathrm{C}$. Protein concentration of each fraction was determined using the Quantipro BCA assay kit (Sigma) according to the manufacturer protocol.

Total RNA was isolated from hippocampus mixture for 3- and 6-month-old WT and $\mathrm{APP}_{\text {Swe }} / \mathrm{PS} 1$ mice using TRIzol reagent method according to the manufacturer's protocol (Sigma) and then digested with deoxyribonuclease to remove any contaminating genomic DNA (Turbo DNA-free from Ambion, Austin, TX).

\section{Quantitative RT-PCR analysis}

RNA quantity and quality was assessed using an Agilent Technologies 2100 bioanalyzer and RNA 6000 Nano LabChip kit (Agilent, Mountain View, CA). Complementary DNA (cDNA) was generated from $40 \mathrm{ng}$ of total RNA using a random primer hexamer following the protocol for Superscript II (Invitrogen, Carlsbad, CA). Equal amounts of cDNA were run in triplicate and amplified in a $15 \mu \mathrm{l}$ reaction containing $7.5 \mu \mathrm{l}$ of $2 \times$ Universal 
PCR Master Mix (Applied Biosystems, Foster City, CA), $10 \mathrm{nM}$ of Z-tailed forward primer, $100 \mathrm{nM}$ of reverse primer, $250 \mathrm{nM}$ of Amplifluor Uniprimer probe (Chemicon, Temecula, California), and $1 \mu \mathrm{l}$ of cDNA target. Moreover, no-template controls were used as recommended. The mixture was incubated at $50^{\circ} \mathrm{C}$ for $2 \mathrm{~min}$, at $95^{\circ} \mathrm{C}$ for $4 \mathrm{~min}$, and then cycled at $95^{\circ} \mathrm{C}$ for $15 \mathrm{~s}$ and at $55^{\circ} \mathrm{C}$ for $30 \mathrm{~s}, 55$ times using the Applied Biosystems Prism 7900 Sequence Detector. Amplification efficiencies were validated and normalized to ribosomal $18 \mathrm{~S}$ gene and quantity of target gene was calculated according to a standard curve. Primers sequences were designed using Primer Express 2.0 (Applied Biosystems) and are described in Table 2. Amplicons were detected using the Amplifluor UniPrimer system, in which forward primers used contained a 5' Z sequence: ACTGAACCTGACCGTACA.

\section{Detection of total A $\beta$ levels by Western blot}

For total $A \beta$ detection, 10-20 $\mu \mathrm{g}$ of extracellular, cytoplasmic, and membrane protein fractions of hippocampus were separated on a precast $4-20 \%$ polyacrylamide Tris-Glycine eXtended (TGX) gel (Bio-Rad). Separated proteins were then transferred onto polyvinylidene fluoride (PVDF) membranes (PerkinElmer Life and Analytical Sciences) and detected by Western blotting. Blots were probed with a mouse anti-amyloid beta protein monoclonal antibody clone $6 \mathrm{E} 10$ (1:1500, Covariance) in $1 \mathrm{M}$ Tris- $\mathrm{HCl}, \mathrm{pH}$ 8.0, $5 \mathrm{M} \mathrm{NaCl}, 5 \%$ skim milk, and $0.05 \%$ Tween 20. Blots were visualized using anti-mouse secondary antibody tagged with horseradish peroxidase (1:1000; Jackson ImmunoResearch) and enhanced chemiluminescence (PerkinElmer Life and Analytical Sciences). Membranes were stripped in $25 \mathrm{mM}$ glycine- $\mathrm{HCl}, \mathrm{pH} 2.0$, containing $1 \%$ SDS to allow $\beta$-actin revelation using first a mouse $\beta$-actin antibody (MAB1501, 1:5000; Millipore Bioscience Research Reagents) and then a goat anti-mouse peroxidase conjugated secondary antibody (1:1000; Jackson ImmunoResearch).

Quantification was done by determining integrative density of the bands using a gel imaging system (scanner Agfa Arcus II; $\mathrm{NIH}$ Image J software version $1.32 \mathrm{j}$ ) and background values were removed. Optical values were normalized according to the actin loading control. Results are expressed as mean \pm SEM.

\section{FACS ANALYSES}

\section{Analysis of circulating monocytes}

Fluorescence-activated cell sorting (FACS) analysis was performed on red blood cell-lysed blood of 5-week- and 6-monthold WT and $\mathrm{APP}_{\mathrm{Swe}} / \mathrm{PS} 1$ mice. Blood of CCR2 $2^{-/-}$mice was used as negative control of CCR2 staining. To analyze the population of monocytes, anti-coagulated whole blood was taken from the facial vein and quickly suspended and cells were washed in Dulbecco's PBS (DPBS) $+4 \%$ fetal bovine serum (FBS). Cells, suspended in DPBS $+2 \%$ FBS, were first incubated on ice for $15 \mathrm{~min}$ with purified rat anti-mouse CD16/CD32 (Mouse BD Fc Bloc, BD Bioscience). The mix was then incubated on ice with Phycoerythrin (PE)-conjugated CD45 antibody (BD Bioscience), PE-Cy7 ${ }^{\mathrm{TM}}$-conjugated CD11b antibody (eBioscience), allophycocyanin (APC)-conjugated CD115 antibody (eBioscience), FITC-conjugated Ly6-C antibody (BD Bioscience), and PerCP-Cy5.5 ${ }^{\mathrm{TM}}$-conjugated Gr1 antibody (Cedarlane) for $35 \mathrm{~min}$. Cells were washed again in DPBS $+2 \%$ FBS. Red blood

Table 2 | Primers sequence for real time PCR.

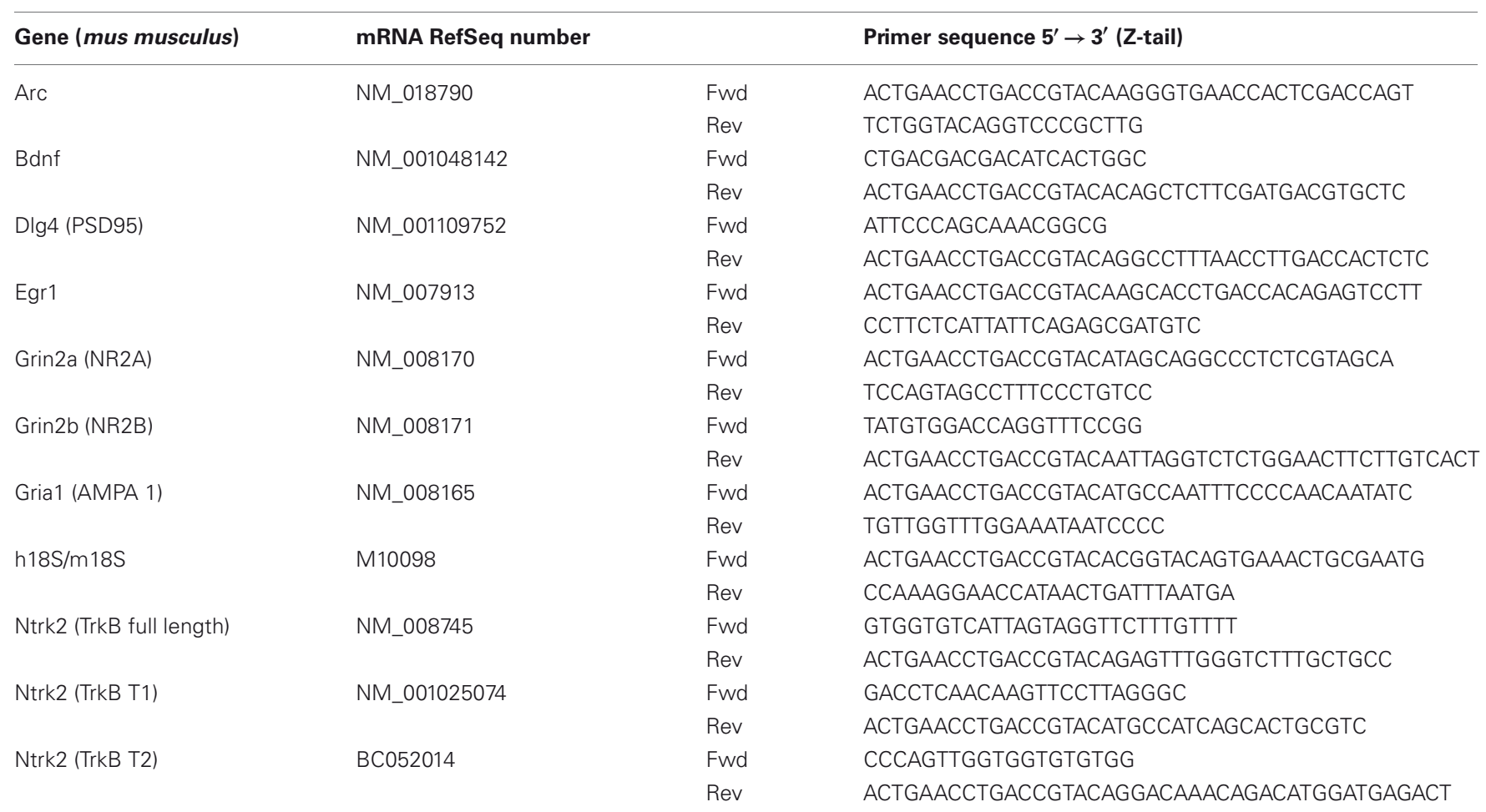


cells were lysed with hemolysin according to the manufacturer's protocol (Beckman Coulter, Mervue, Galway, Ireland) and cells were washed with DPBS and re-suspended in equal volumes of DPBS. For CCR2 detection, washed cells were first incubated on ice with monoclonal antibody MC-21 (anti-CCR2) for $60 \mathrm{~min}$ (Mack et al., 2001). After washing, cells were incubated for $60 \mathrm{~min}$ on ice with a biotin-labeled anti-rat polyclonal antibody (BD Bioscience). Cells were washed again and incubated with purified rat anti-mouse CD16/CD32 on ice for $15 \mathrm{~min}$, before adding PerCP ${ }^{\mathrm{TM}}$-labeled streptavidin (BD Bioscience) and the combination of directly conjugated antibodies as described previously (Mack et al., 2001). Cells were analyzed using a two-lasers and six color FACS Canto II flow cytometer and data acquisition was done with BD Facs Diva software (version 6.1.2, BD Biosciences, Mississauga, ON, Canada). Cells were then sorted according to the different fluorescent antibodies. Results were analyzed using Flow Jo software (Tristar).

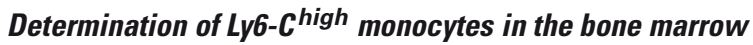

Male WT and $\mathrm{APP}_{\text {Swe }} / \mathrm{PS} 1$ mice, 6-6.5 months of age, were used to determine the frequency of inflammatory monocytes in the bone marrow. The cells were aseptically harvested for each mice by flushing the two tibias and femurs with DPBS containing 2\% FBS. Cell samples were combined for each mouse, filtered through a $40-\mu \mathrm{m}$ nylon mesh, centrifuged, and were washed with DPBS and re-suspended in equal volumes of DPBS $+2 \%$ FBS. Cells were first incubated on ice for 15 min with purified rat anti-mouse CD16/CD32 (Mouse BD Fc Bloc, BD Bioscience). The mix was then incubated on ice with PE-conjugated CD11b antibody (BD Bioscience), horizon V500-conjugated CD45 antibody (BD Bioscience), and Pacific blue-conjugated Ly6-C antibody (Biolegend) for $35 \mathrm{~min}$. Cells were analyzed using a two-lasers and six color FACS Canto II flow cytometer and data acquisition was done with BD Facs Diva software (version 6.1.2, BD Biosciences, Mississauga, ON, Canada). Cells were then sorted according to the different fluorescent antibodies. Results were analyzed using Flow Jo software (Tristar).

\section{MACROPHAGE COLONY-STIMULATING FACTOR (M-CSF) TREATMENT}

WT and $\mathrm{APP}_{\text {Swe }} / \mathrm{PS} 1$ mice received daily an ip injection of murine $\mathrm{M}-\mathrm{CSF}(40 \mu \mathrm{g} / \mathrm{Kg})$ (R\&D Systems) during 4 days at the age of 3 or 6 months and were tested 3 months later in the T-maze paradigm. The experimental procedure for these two protocols is depicted in the Figure 8. The first experiment consisted to treat animals before the occurrence of mnesic impairments and $A \beta$ pathology (Figure 8A), whereas in the second experiment animals were administered after the occurrence of cognitive decline, synaptic disruption and $\mathrm{A} \beta$ pathology (Figure 8D).

To determine the potential role of CCR2 in mediating the effects of M-CSF on monocytes, WT, CCR2, $\mathrm{APP}_{\text {Swe }} / \mathrm{PS} 1$, and $\mathrm{APP}_{\text {Swe }} / \mathrm{PS} 1 / \mathrm{CCR} 2^{-/-}$mice received daily ip injections of the cytokine $(40 \mu \mathrm{g} / \mathrm{Kg})$ during 4 days at the age of 3.5-4 months. Twenty-four hours after the fourth injection, the whole blood was taken from the facial vein to perform FACS analysis. As previously explained, $\mathrm{PE}-\mathrm{Cy} 7^{\mathrm{TM}}$-conjugated CD11b antibody
(eBioscience), PE-conjugated CD45 antibody (BD Bioscience), and APC-conjugated CD115 antibody (eBioscience) were used to determine the population of monocytes.

\section{STATISTICAL ANALYSES}

Results are expressed as the mean \pm SEM. Statistical analysis was performed by one- or two-way analysis of variance (ANOVA), followed by the appropriate test procedure, using Bonferroni or Tamhane's tests as post-hoc comparisons (SPSS software). Data were analyzed using standard two-tailed unpaired $t$-test's for the comparison between two groups. Correlations were estimated by linear regression analysis and the Spearman's correlation coefficient (GraphPad Software Inc.) with $p$ - and $r$-values and 95\% confidence intervals included in the graph. A $p$-value $<0.05$ was considered statistically significant.

\section{RESULTS}

\section{THE OCCURRENCE OF MNESIC IMPAIRMENTS DOES NOT CORRELATE WITH A $\beta$ DEPOSITS}

Coronal brain sections of $\mathrm{WT}$ and $\mathrm{APP}_{\mathrm{Swe}} / \mathrm{PS} 1$ mice at 3 and 6 months of age were immunostained with the $6 \mathrm{E} 10$ antibody specific for the 1-16 fragment of the human $A \beta$ protein. Plaques surface were determined by stereological analysis in hippocampus. $\mathrm{A} \beta$ deposits are scarce in 3-month-old $\mathrm{APP}_{\text {Swe }} / \mathrm{PS} 1$ mice (Figures 1A-B). Indeed, insoluble $A \beta$ begins to accumulate at 6 months of age (Figures 1A-B). Density and area occupied by $A \beta$ deposits are robustly increased in hippocampus at 6 months of age (Figures 1A-B). These results seem to support a positive correlation between the onset of plaque formation and cognitive impairment. Therefore, we investigated if mnesic deficit correlated positively with $A \beta$ load at the age of 6 months. We determined the correlation between spatial memory decline (water T-maze test) and the percentage area occupied by plaque in hippocampus in each 6-month-old $\mathrm{APP}_{\text {Swe }} / \mathrm{PS} 1$ mice. Surprisingly no correlation was observed for both structures (Figure 1C).

As mnesic impairments occurred at 6 months of age (Naert and Rivest, 2011a), we precisely compared the hippocampal level of soluble $\mathrm{A} \beta$ oligomers in $\mathrm{APP}_{\text {Swe }} / \mathrm{PS} 1$ mice at 3 and 6 months of age. Using a modified version of the Lesné's protocol (Lesné et al., 2006), we performed western blotting for extracellularand intracellular-enriched proteins. The different $A \beta$ oligomers were revealed using the $6 \mathrm{E} 10$ antibody. In the extracellularenriched fraction, 6-month-old $\mathrm{APP}_{\mathrm{Swe}_{\mathrm{w}}} / \mathrm{PS} 1$ mice exhibited an important increase of low-n oligomers. Indeed levels of 8-, 6-, and 1-mer were significantly increased (Figures 1D-E). In the intracellular fraction, soluble oligomers (12-, 6-, and 3 -mer) were augmented (Figures $\mathbf{1 F}-\mathbf{G}$ ). Therefore, a robust accumulation of soluble $A \beta$ occurred in hippocampus of 6-month-old $\mathrm{APP}_{\text {Swe }} / \mathrm{PS} 1$ mice.

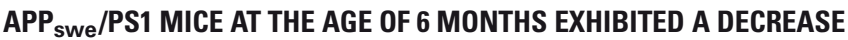 IN TRANSCRIPT LEVEL OF BDNF AND ITS RECEPTORS IN HIPPOCAMPUS}

As mnesic impairment appeared at the age of 6 months in $\mathrm{APP}_{\text {Swe }} / \mathrm{PS} 1$ mice, we compared the BDNF transcript levels in $\mathrm{WT}$ and $\mathrm{APP}_{\text {Swe }} / \mathrm{PS} 1$ mice at 3 and 6 months of age. WT and 

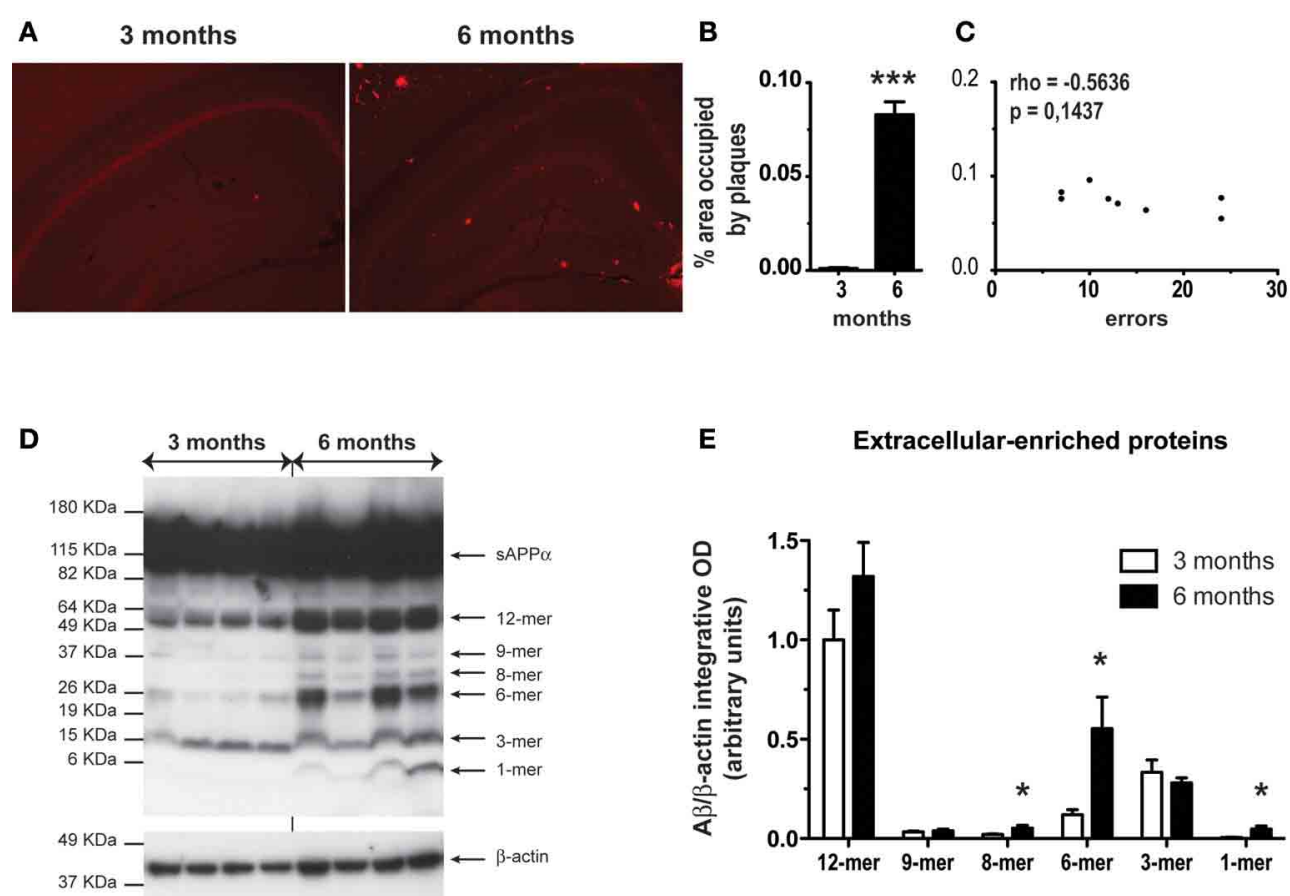

E Extracellular-enriched proteins
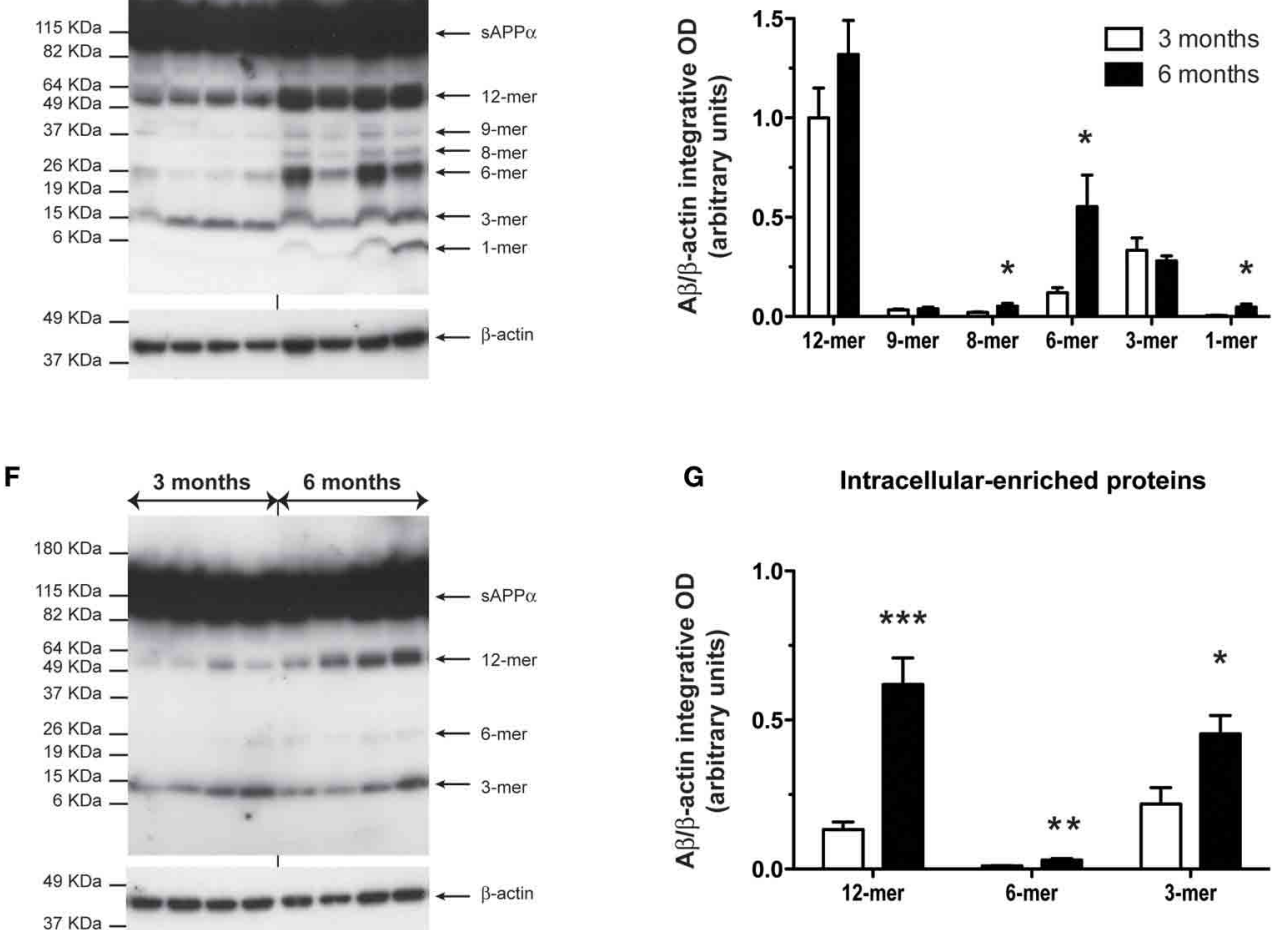

FIGURE 1|Six-month-old APP Swe $_{\text {w }}$ /PS1 mice had higher level of $A \beta$ soluble oligomers in the hippocampus. Anti- $A \beta$ immunoreactivity is depicted in hippocampus of APP swe $/$ PS1 at 3 and 6 months of age (A). A detailed analysis of plaque quantification was performed to determine the percentage area occupied by plaques (B) of 3- and 6-month-old $\mathrm{APP}_{\text {swe }} / \mathrm{PS} 1$. A $\beta$ load was strongly increased at 6 months age in hippocampus. A correlation's test revealed no significant correlation between spatial memory decline (water T-maze test) and the percentage area occupied by plaques at the age of mnesic deficit occurrence (6 months) (C). Therefore, the hippocampus level of soluble $A \beta$ was

\section{G Intracellular-enriched proteins}

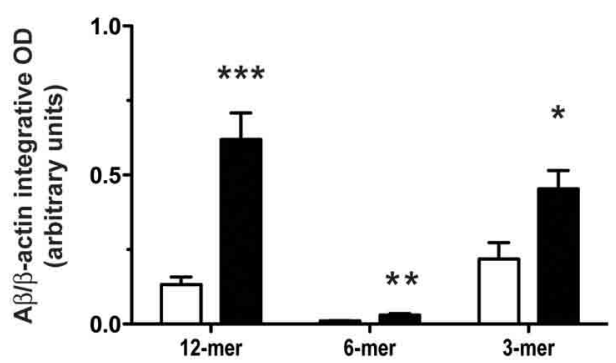

analyzed by western blotting for extracellular and intracellular-associated proteins of 3- and 6-month-old APPswe/PS1 mice. The intensity of each band was quantified by densitometric analysis and normalized per $\beta$-actin values. $A \beta$ species ratios (A $/ \beta$-actin) are represented and increased levels of $A \beta$ soluble oligomers were observed at 6 months of age in extracellular (D-E) and intracellular (F-G). Results are expressed as the Mean \pm SEM; $n=6-7$; Student's $t$-test; ${ }^{*} p<0.05,{ }^{* *} p<0.01$ and ${ }^{* * *} p<0.001 .{ }^{*}$ vs. APP Swe $/$ PS1 at 3 months of age. Magnification $4 \times$. Correlation test was performed using the Spearman's correlation coefficient.
$\mathrm{APP}_{\text {Swe }} / \mathrm{PS} 1$ mice exhibited similar expression of BDNF mRNA in hippocampus at 3 months of age, as revealed by hybridization in situ (Figure 2A) and quantitative RT-PCR analysis (Figure 2B). On the other hand, 6-month-old $\mathrm{APP}_{\text {Swe }} / \mathrm{PS} 1$ mice had lower BDNF mRNA levels in hippocampus, a $41 \%$ reduction was highlighted by quantitative RT-PCR analysis (Figure 2B). BDNF activity is dependent on TrkB and its downstream targets and levels of the different isoforms of TrkB-TrkB full length (TrkB.FL), TrkB
T1, and TrkB T2-were assessed by quantitative RT-PCR analysis in hippocampus. WT and $\mathrm{APP}_{\text {Swe }} / \mathrm{PS} 1$ mice expressed similar TrkB.FL, TrkB T1, and TrkB T2 mRNA levels at 3 months of age (Figures 2C-E), whereas these transcript levels were significantly reduced by 27,29 , and $35 \%$, respectively, in 6-month-old $\mathrm{APP}_{\text {Swe }} / \mathrm{PS} 1$ mice (Figures 2C-E). These data suggest that the BDNF system is affected in the in hippocampus of 6-month-old $\mathrm{APP}_{\text {Swe }} / \mathrm{PS} 1$ mice. 

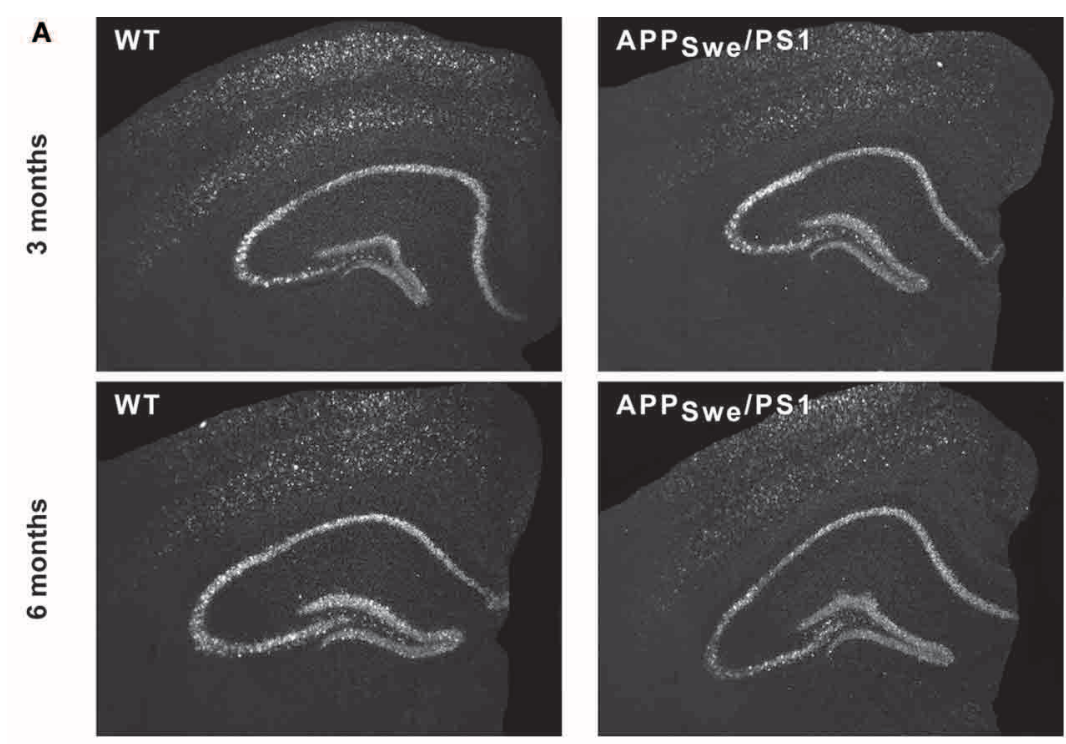

C

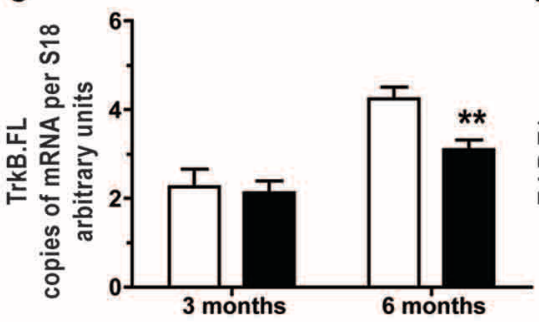

D

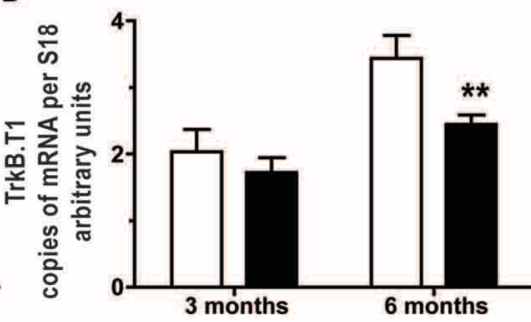

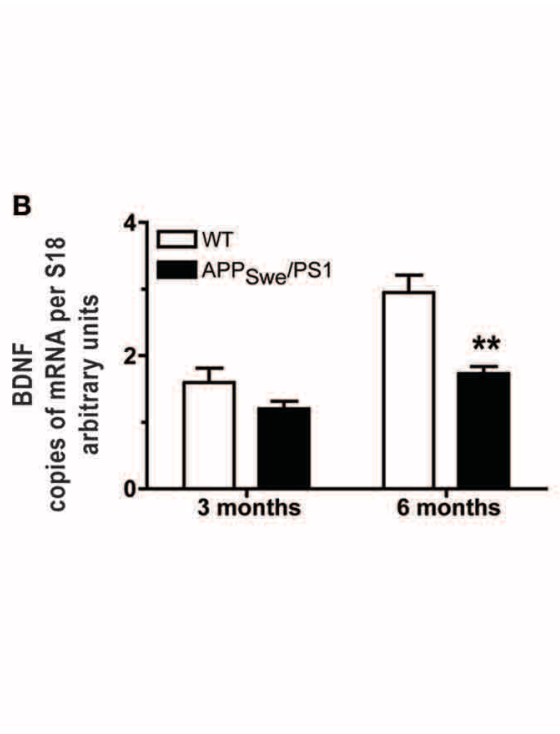

E

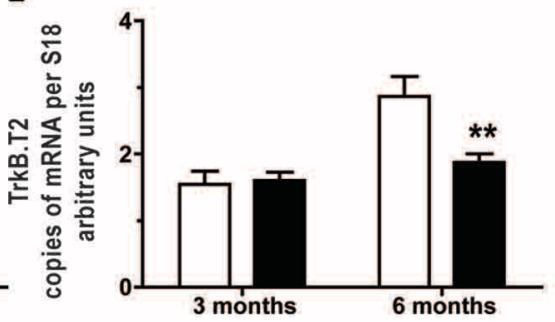

FIGURE 2 | Expression of BDNF and its receptors decreased in hippocampus when mnesic deficits begin in APP $_{\text {Swe }} / \mathrm{PS} 1$ mice. Representative dark-field photomicrographs of in situ hybridization showed the hippocampal expression of BDNF mRNA (A) in the brain

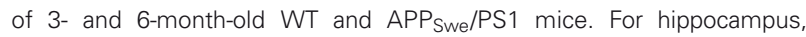
mRNA levels of BDNF and its receptors-TrkB.FL, TrkB.T1, and TrkB.T2-were determined by real-time $\mathrm{GPCR}$ and normalized relative to the level of S18 mRNA detected in each sample. At 3 months of age, APP $_{\text {swe }} /$ PS1 mice exhibited similar mRNA levels of BDNF (A and B) and its receptors, TrkB.FL (C), TrkB.T1 (D), and TrkB.T2 (E). In contrast, all transcripts were significantly decreased in 6 month-old $\mathrm{APP}_{\text {Swe }} / \mathrm{PS} 1$ mice compare to WT littermates (B-E). Results are expressed as the Mean \pm SEM; $n=5-9$; Student's $t$-test; ${ }^{* *} p<0.01$ vs. WT at the same age.

\section{DECREASED EXPRESSION OF GENES ENCODING SYNAPTIC PROTEINS THAT ARE CRITICAL FOR MEMORY AND LEARNING IN THE

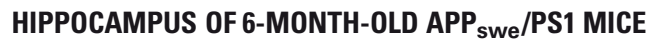

Expression of pre- and post-synaptic genes was assessed in hippocampus by in situ hybridization and RT-PCR. We performed in situ hybridization for Egr1, Arc, NMDA-R1 (NR2A), and -R2 (NR2B) transcripts in hippocampus of 3- and 6-month-old $\mathrm{WT}$ and $\mathrm{APP}_{\text {Swe }} / \mathrm{PS} 1$ mice (Figure 3). At 3 months of age, $\mathrm{WT}$ and $\mathrm{APP}_{\text {Swe }} / \mathrm{PS} 1$ mice exhibited similar signal for all transcripts, whereas a decreased signal for Egr1, Arc, NR2A, and NR2B mRNA was observed in the hippocampus of 6-month-old $\mathrm{APP}_{\text {Swe }} / \mathrm{PS} 1$ mice (Figure 3). These results were confirmed using RT-PCR analysis (Figure 4). Similar expression levels of these transcripts were quantified in the hippocampus at 3 months of age. However, Egr1, Arc, NR2A and NR2B, AMPA1, and PSD95 mRNA levels were significantly lower by 48, 47, 29, 27, 21, and $22 \%$, respectively, in $\mathrm{APP}_{\text {Swe }} / \mathrm{PS} 1$ mice then their WT littermates (Figure 4). These data highlight a defect in synaptic markers in hippocampus of 6-month-old $\mathrm{APP}_{\text {Swe }} / \mathrm{PS} 1$ mice.

\section{FREQUENCY OF LY6-Chigh GR1+ CCR2+ MONOCYTES IS SIGNIFICANTLY REDUCED IN THE BLOODSTREAM AND THE BONE MARROW OF 6-MONTH-OLD APP swe/PS1 MICE}

To assess whether monocytes were affected in a context of $\mathrm{AD}$ and whether the occurrence of memory deficit may be linked with impairment of the innate immune system, we determined the frequency of monocytes in $\mathrm{WT}$ and $\mathrm{APP}_{\text {Swe }} / \mathrm{PS} 1$ mice before (5 weeks of age) and at the beginning of the mnesic deficit (6 months of age). Leukocytes were labeled with CD45 and monocytes were distinguished using CD11b and CD115 (CSF1/MCSF receptor). At 5 weeks $\mathrm{WT}$ and $\mathrm{APP}_{\text {Swe }} / \mathrm{PS} 1$ mice exhibited similar frequency of $\mathrm{CD} 45^{+} \mathrm{CD} 11 \mathrm{~b}^{+} \mathrm{CD} 115^{+}$cells (Figures 5A and $\mathbf{C}$ ) and this monocyte number significantly increased in 6-month-old WT mice as depicted in the Figure 5C. Such a phenomenon has previously been described (Boggs et al., 1986). Of great interest is that monocyte frequency did not increase in 6-month-old $\mathrm{APP}_{\text {Swe }} / \mathrm{PS} 1$ mice and their circulating monocyte number remained at the level of the young 5 week-old animals (Figures 5A-C). 

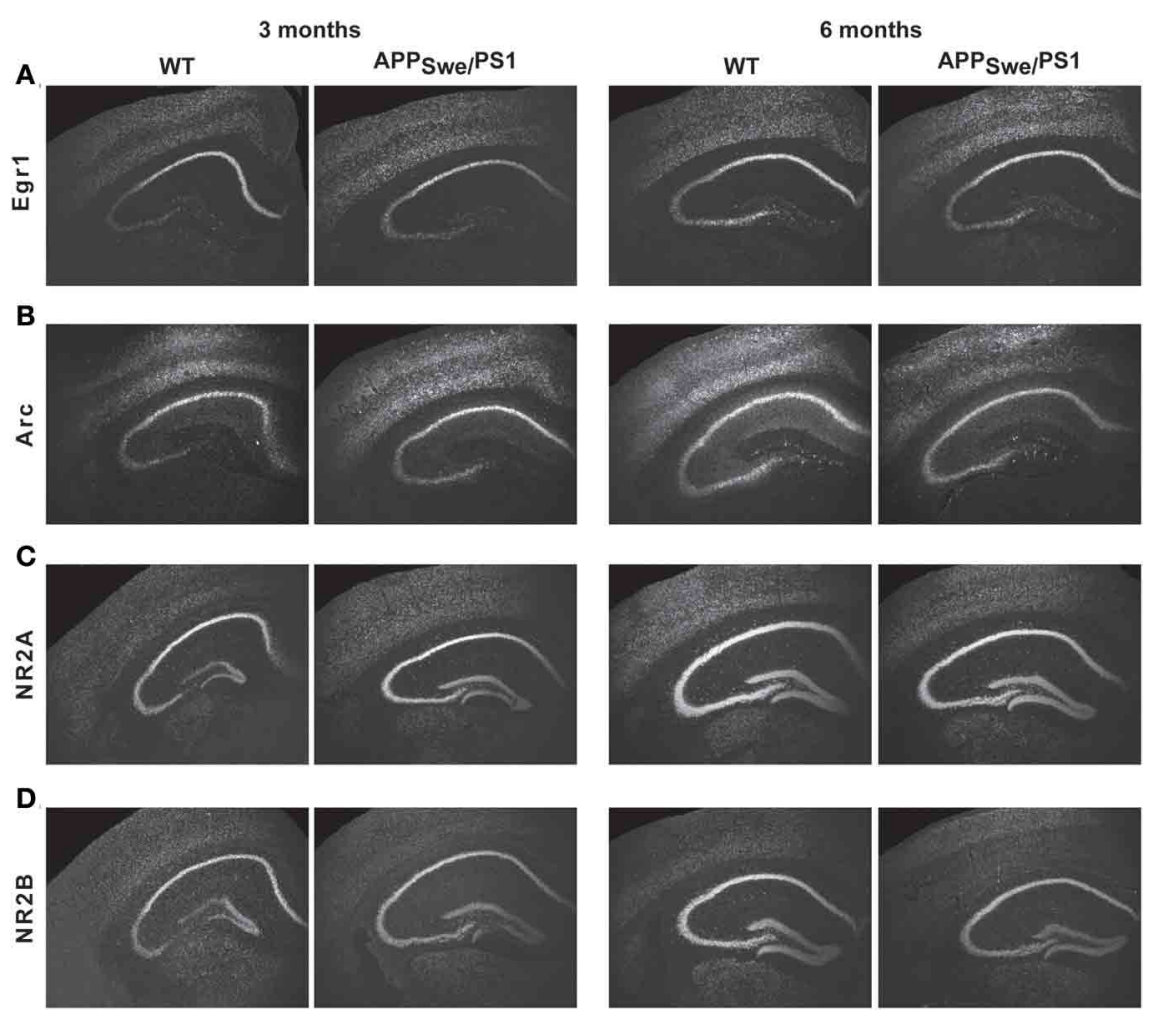

FIGURE 3 | Egr1, Arc, NR2A, and NR2B transcript levels in APP $_{\text {Swe }}$ /PS1 mice. Expression of Egr1, Arc, PSD95, AMPA1, NR2A, and NR2B mRNA were determined by in situ hybridization. Three-month-old WT and APP $_{\text {swe }} /$ PS1 mice had similar mRNA levels of Egr1
(A), Arc (B), NR2A (C), and NR2B (D). In contrast, intensity of transcript signal for Egr1 (A), Arc (B), NR2A (C), and NR2B (D) was lower in the brain of $\mathrm{APP}_{\text {Swe }} / \mathrm{PS} 1$ mice than WT mice at 6 months of age. Magnification $4 \times$.
We then distinguished between the inflammatory subset $\mathrm{CX}_{3} \mathrm{CR} 1^{\text {low }} \mathrm{Ly} 6-\mathrm{C}^{\text {high }} \mathrm{Gr} 1^{+} \mathrm{CCR} 2^{+}$and the patrolling monocyte $\mathrm{CX}_{3} \mathrm{CR} 1^{\text {high }}{ }^{\mathrm{Ly} 6}-\mathrm{C}^{\text {low }} \mathrm{Gr} 1^{-} \mathrm{CCR} 2^{-}$by the expression of $\mathrm{Gr} 1$ (Figure 6). At 5 weeks of age, WT and $\mathrm{APP}_{\text {Swe }} / \mathrm{PS} 1$ mice exhibited similar frequency of each subset (Figures 6A-D). The ratio of $\mathrm{Gr}^{+}$and $\mathrm{Gr}^{-}$monocyte is $\sim 60 \%$ and $\sim 40 \%$, respectively, in both group of mice (Figures 6A-D). At 6 months of age the frequency of $\mathrm{Gr}^{-}$monocytes was similar between $\mathrm{WT}$ and $\mathrm{APP}_{\text {Swe }} / \mathrm{PS} 1$ mice (Figures 6B and D), but the proportion of $\mathrm{Gr}^{+}$is reduced by almost 3 fold in 6-month-old $\mathrm{APP}_{\text {Swe }} / \mathrm{PS} 1$ mice compared to their WT littermates (Figures 6A and $\mathbf{C})$. This group of WT mice had $\sim 70 \%$ of $\mathrm{Gr}^{+}$and $\sim 30 \% \mathrm{Gr}^{-}$monocyte, which is 2 fold more $\mathrm{Grl}^{+}$subset than their $\mathrm{APP}_{\text {Swe }} / \mathrm{PS} 1$ progeny (Figures $6 \mathrm{C}$ and $\mathrm{D}$ ). To confirm these results we used Ly6-C and CCR2 to further distinguish between the different subsets of monocytes. Blood of CCR2-deficient mice was used as negative control for the CCR2 antibody used in this study (data not shown). According to the previous observation, we found a marked decrease of Ly6-C ${ }^{\text {high }} \mathrm{CCR} 2^{+}$monocytes in 6-month-old $\mathrm{APP}_{\text {Swe }} / \mathrm{PS} 1$ mice (Figures 6G-H), while Ly6- $\mathrm{C}^{\text {int }}$ and Ly6-C $\mathrm{C}^{\text {low }}$ monocytes remained similar in $\mathrm{WT}$ and $\mathrm{APP}_{\text {Swe }} / \mathrm{PS} 1$ mice at the same age (data not shown).

To explain the defect in circulating Ly6-C $\mathrm{C}^{\text {high }}$ monocytes, we assessed the frequency of this monocyte subset in the bone marrow of 6-month-old $\mathrm{APP}_{\text {Swe }} / \mathrm{PS} 1$ mice. Using the common leukocyte antigen CD45, we found a similar frequency and number of $\mathrm{CD}_{4} 5^{+}$cells in both WT and $\mathrm{APP}_{\text {Swe }} / \mathrm{PS} 1$ groups of mice at 6 months of age (Figure 7A). CD11b and Ly6-C were consequently used to identify the inflammatory monocyte subset among these $\mathrm{CD} 45^{+}$cells and $\mathrm{APP}_{\text {Swe }} / \mathrm{PS} 1$ mice had significantly less Ly6-Chigh monocytes in their bone marrows than WT littermates (Figure 7B). This interesting result suggests strongly that the production of Ly6-C $\mathrm{C}^{\text {high }}$ monocytes is decreased in the bone marrow of 6-month-old $\mathrm{APP}_{\mathrm{Sw}_{\mathrm{w}}} / \mathrm{PS} 1$ mice. There is consequently a clear defect of the hematopoietic system to produce Ly6-C ${ }^{\text {high }} \mathrm{CCR}^{+}$monocytes in 6-month-old $\mathrm{APP}_{\text {Swe }} / \mathrm{PS} 1$ mice and this correlates with the beginning of the cognitive decline of this mouse model of AD.

\section{A SHORT MACROPHAGE COLONY-STIMULATING FACTOR (M-CSF) TREATMENT INCREASES MONOCYTE FREOUENCY IN APP swe/PS1 $_{1}$ MICE AND RESCUES THEIR COGNITIVE IMPAIRMENT}

To assess whether defect in the population of monocytes is due to their inability to differentiate properly and is a non-reversible mechanism, we assessed the effect of the main hematopoietic cytokine involved in monocytopoeisis, M-CSF, in $\mathrm{APP}_{\text {Swe }} / \mathrm{PS} 1$ mice. A short treatment with M-CSF (once/day, during 4 days) was administered in $\mathrm{APP}_{\mathrm{Swe}} / \mathrm{PS} 1$ mice before (at 3 months) and after the occurrence of cognitive decline (at 6 months). 

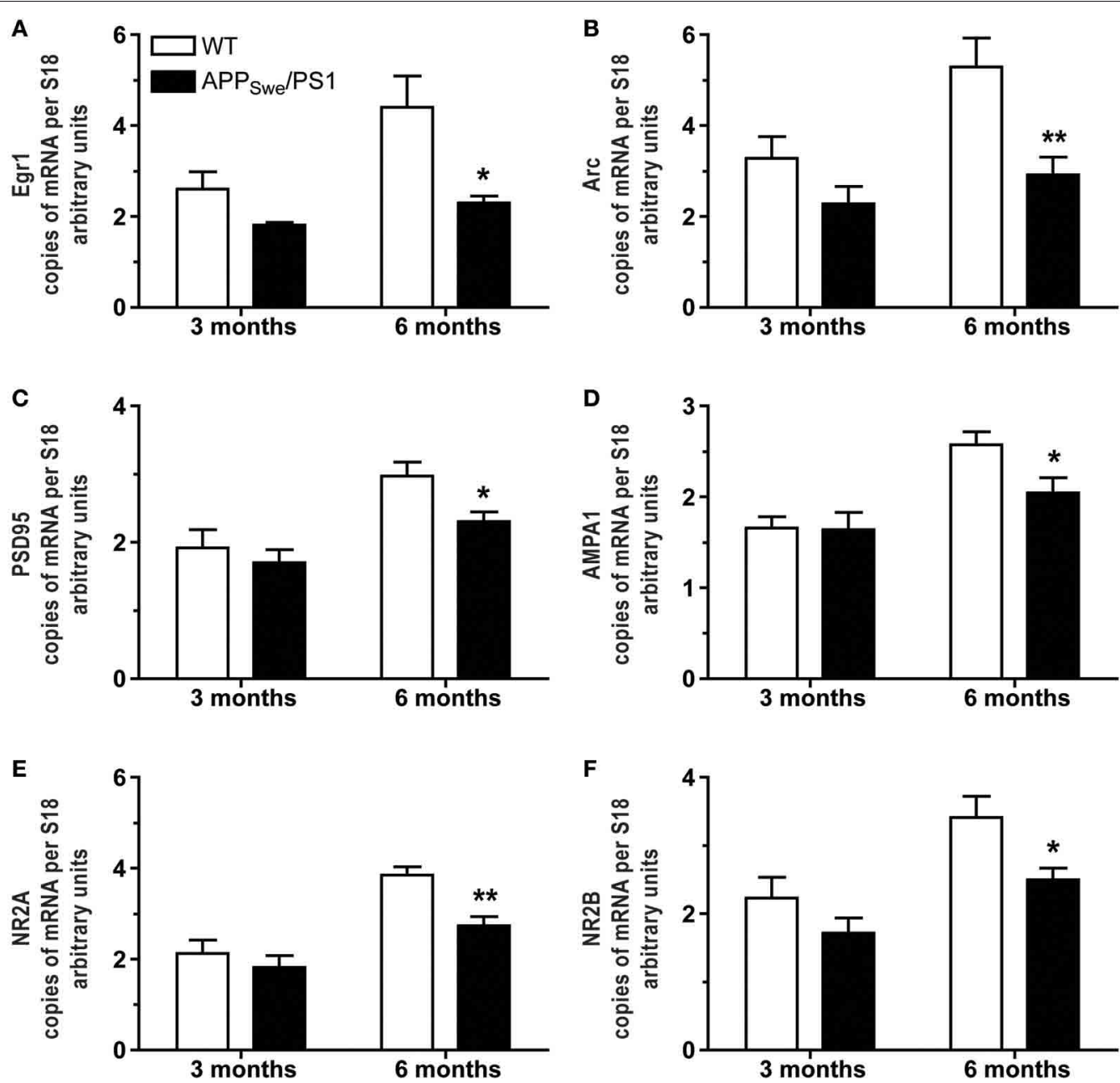

FIGURE 4 | Occurrence of mnesic deficits correlate with decreased mRNA levels of synaptic markers in hippocampus of $\mathrm{APP}_{\mathrm{Swe}} / \mathrm{PS} 1$ mice. Real-time qPCR was used to quantify Egr1, Arc, PSD95, AMPA1, NR2A, and NR2B mRNA levels in the hippocampus. The values were normalized relative to the level of S18 mRNA detected in each sample. 3-month-old WT and

APP $_{\text {Swe }}$ /PS1 mice had similar mRNA levels of Egr1 (A), Arc (B), PSD95 (C), AMPA1 (D), NR2A (E), and NR2B (F). In contrast, all transcripts were

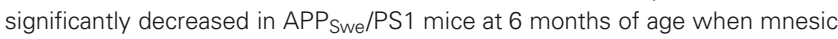
deficits begin. Results are expressed as the Mean \pm SEM; $n=5-9$; Student's $t$-test; ${ }^{*} p<0.05$ and ${ }^{* *} p<0.01$ vs. WT at the same age.

Spatial memory of these mice was assessed 3 months later using the water T-maze test (Figures $\mathbf{8 A}$ and D). M-CSF was able to prevent the apparition of memory impairment, which occurred normally at 6 months, as revealed by the number of trials $\left(10.4 \pm 1.4\right.$ vs. $17.4 \pm 1.7$ for $\mathrm{APP}_{\text {Swe }} / \mathrm{PS} 1$ mice; $\left.p<0.05\right)$ (Figures 8A-C). M-CSF did also restore mnesic capacity-MCSF-treated $\mathrm{APP}_{\text {Swe }} / \mathrm{PS} 1$ mice at 9 months of age exhibited a significant decrease of the number of trials (9.2 \pm 1.9 vs. $21.4 \pm$ 1.1 for $\mathrm{APP}_{\text {Swe }} / \mathrm{PS} 1$ mice; $p<0.001$ ) (Figures 8D-F).

To determine whether M-CSF had the same effect on monocytic commitment in WT and $\mathrm{APP}_{\text {Swe }} / \mathrm{PS} 1$ mice, we performed FACS analysis on blood cells $24 \mathrm{~h}$ after the fourth injection of MCSF $(40 \mu \mathrm{g} / \mathrm{Kg} / \mathrm{day})$. Such a treatment increased the number of monocytes $\left(\mathrm{CD} 11 \mathrm{~b}^{+} \mathrm{CD} 115^{+}\right)$within the population of $\mathrm{CD} 45^{+}$ cells (Figure 9). M-CSF caused a similar increase of monocyte frequency in $\mathrm{APP}_{\mathrm{Swe}} / \mathrm{PS} 1$ mice (Figure 9). This effect of M-CSF was dependent on CCR2, because the cytokine failed to increase the population of monocytes in $\mathrm{CCR} 2^{-/-}$and $\mathrm{APP}_{\mathrm{Swe}} / \mathrm{PS} 1 /$ $\mathrm{CCR}^{-/-}$mice (Figure 9).

\section{DISCUSSION}

Immune system is a key feature in $\mathrm{AD}$ pathology, but its role has yet to be fully unraveled. Here, we have analyzed monocyte subset frequency associated to age-dependent amyloid pathological progression in $\mathrm{APP}_{\text {Swe }} / \mathrm{PS} 1$ mice. The main findings are the reduced levels of monocytes, due to the decreased frequency of $\mathrm{CX}_{3} \mathrm{CR} 1^{\text {low }} \mathrm{Ly} 6-\mathrm{C}^{\text {high }} \mathrm{Gr} 1^{+} \mathrm{CCR} 2^{+}$subset in bloodstream and bone marrow of 6-month-old $\mathrm{APP}_{\mathrm{Swe}} / \mathrm{PS} 1$ mice. This defect in monocyte levels corresponds to the onset of memory impairment, synaptic disruption, down-regulation of neuroprotective factor, and an enhanced accumulation of soluble $A \beta$ in hippocampus.

While density and area of $A \beta$ plaques do not closely correspond to the degree of dementia, increased levels of soluble $\mathrm{A} \beta$ seem more closely associated with cognitive decline in $\mathrm{AD}$ 


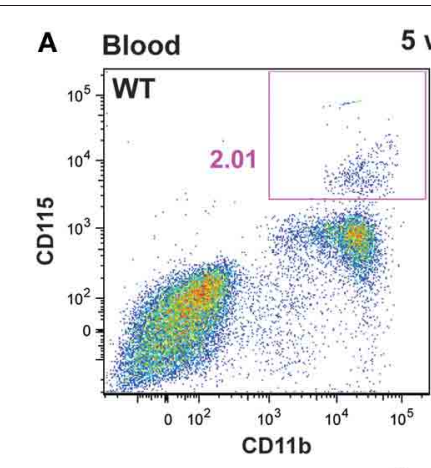

5 weeks
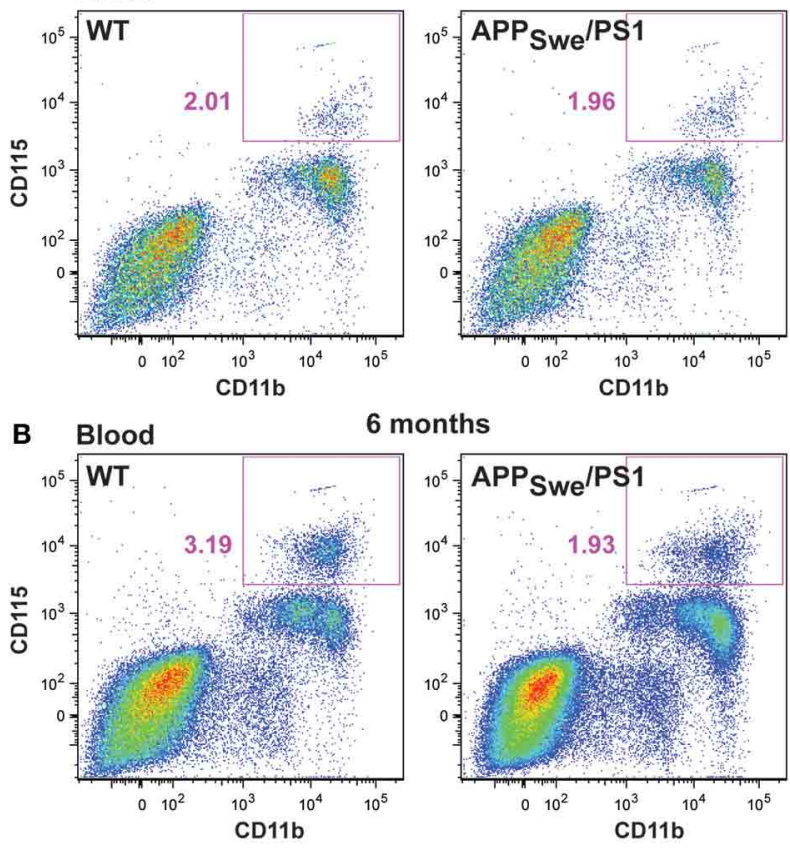

6 months

C

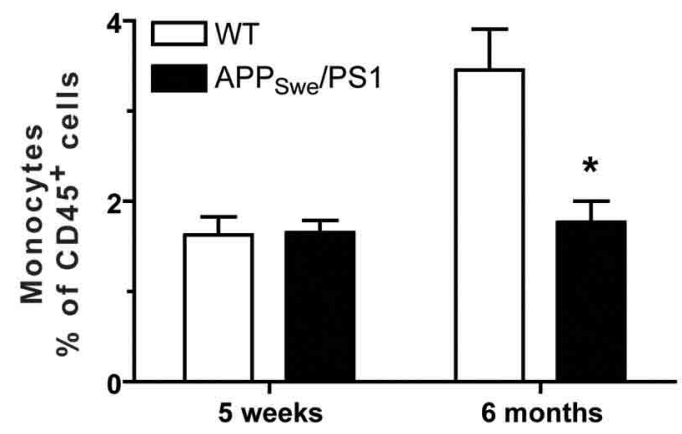

FIGURE 5 | Monocyte levels are drastically diminished in 6-month-old APP $_{\text {swe }} /$ PS1 mice. Circulating monocyte numbers were determined by FACS analysis within the population of leukocytes $\left(C D 45^{+}\right)$in the blood of WT and APP swe /PS1 mice at 5 weeks and 6 months of age. Monocytes were characterized by CD11b and CD115 expression and were quantified within the population of $\mathrm{CD} 45^{+}$cells. At 5 weeks of age, WT and $\mathrm{APP}_{\text {swe }} / \mathrm{PS} 1$ mice exhibited similar levels of monocytes (A and $\mathbf{C}$ ). In

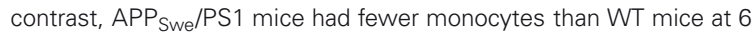
months of age (B and $\mathbf{C}$ ). Results are expressed as the Mean \pm SEM; $n=7-8$; Student's $t$-test; $* p<0.05 ; *$ vs. WT at the same age.

(Lue et al., 1999; McLean et al., 1999; Naslund et al., 2000; Lesné et al., 2006, 2008; Cheng et al., 2007). As we previously observed in others mouse models of AD (Richard et al., 2008; Naert and Rivest, 2011a, 2012), neither onset nor intensity of the memory decline correlated with the senile plaques at all ages studied in $\mathrm{APP}_{\text {Swe }} / \mathrm{PS} 1$ mice. A significant increase of intra- and extracellular pools of $A \beta$ was found in hippocampus of 6-month-old $\mathrm{APP}_{\text {Swe }} / \mathrm{PS} 1$ mice. This increase occurred concomitantly with the apparition of mnesic impairments and the deficit of synaptic markers. Soluble $A \beta$ was detected before plaque formation, synaptic impairments, neurotrophin deficits, and memory decline (at 3 months of age). In the Tg2576 model, memory impairment begins 6 months before plaque formation when $A \beta$ dimers start to accumulate (Kawarabayashi et al., 2004). Indeed soluble $A \beta$ can induce cognitive impairment (Larson and Lesné, 2011), such as extracellular $A \beta^{\star 56}$ (Lesné et al., 2006) or soluble $\mathrm{A} \beta$ dimer and trimer (Cleary et al., 2005; Shankar et al., 2008). In AD patients, soluble intracellular and membraneassociated $A \beta$ in temporal neocortex is more closely related to $\mathrm{AD}$ symptoms than other $\mathrm{A} \beta$ species (Steinerman et al., 2008). Increased levels of intraneuronal $A \beta$ aggravated the mnesic deficit in $\mathrm{APP}_{\mathrm{Swe}} / \mathrm{PS} 1 / \mathrm{CCR} 2^{-/-}$mice (Naert and Rivest, 2011a), suggesting that accumulation of soluble intraneuronal $A \beta$ is a key feature for the synaptic pathology in AD.

Synaptic plasticity is involved in learning and memory, and requires the expression of proteins able to mediate changes necessary for the increase in synaptic strength and memory. Alterations in synapses appear to be among the earliest events in the initiation of the cognitive decline that characterize $\mathrm{AD}$ and have long been considered the best pathological correlates of cognitive decline in $\mathrm{AD}$ (Coleman and Yao, 2003). Correlations between alterations in BDNF expression and/or function and mechanisms occurring in $\mathrm{AD}$ are well established (Connor et al., 1997; Tapia-Arancibia et al., 2008). Here we also observed a strong decrease of BDNF mRNA in hippocampus of 6-month-old $\mathrm{APP}_{\mathrm{Swe}} / \mathrm{PS} 1$ mice. At the same time the different isoforms of its specific receptors, TrkB-TrkB FL, T1, and T2-are all down-regulated. Expression of BDNF is significantly reduced in $\mathrm{AD}$ and mildly cognitively impaired patients (Tapia-Arancibia et al., 2008). Recently, impaired TrkB receptor signaling was reported to contribute to memory impairments in $\mathrm{APP}_{\text {Swe }}$ /PS1 dE9 mice (Kemppainen et al., 2012). The BDNF gene delivered into amyloid-transgenic mice was found to reverse synapse loss, resulting in partial recovery of synaptic markers, and restoration of learning and memory (Nagahara et al., 2009).

In addition the immediate early genes Arc and Egr1, which are clearly involved in learning and memory processes in hippocampus, were drastically reduced in 6-month-old $\mathrm{APP}_{\text {Swe }} / \mathrm{PS} 1$ mice. Subunits of ionotropic glutamate receptors, NMDA (NR2A and NR2B) and AMPA (AMPA1), and PSD95 were also significantly decreased in the hippocampus of these mice. Overexpression of the NR2B subunit leads to improved memory function (Tang et al., 1999), whereas hippocampal injection of antisense oligonucleotides directed against NR2B mRNA inhibits cognitive functions (Clayton et al., 2002). These molecules (e.g., AMPA1 and PSD-95) are critical for synaptic plasticity (Malinow and Malenka, 2002). PSD-95 is involved in recruiting and holding glutamate receptors at the surface (Xiao et al., 1998; Ango et al., 2000) and Arc expression is also closely related to NMDA activity (Bloomer et al., 2008). BDNF stimulates Arc expression in neurons by a mechanism that involves the $\operatorname{TrkB}$ receptor and is also dependent on the NMDA glutamate receptor (Yin et al., 2002). BDNF plays a key role in regulating expression and synaptic delivery of AMPA receptor subunits (Li and Keifer, 2009) and it regulates the synaptic localization of PSD95 via a TrkB-dependent mechanism (Yoshii et al., 2011) and enhances AMPA trafficking to cell membrane (Li and Keifer, 2009). 

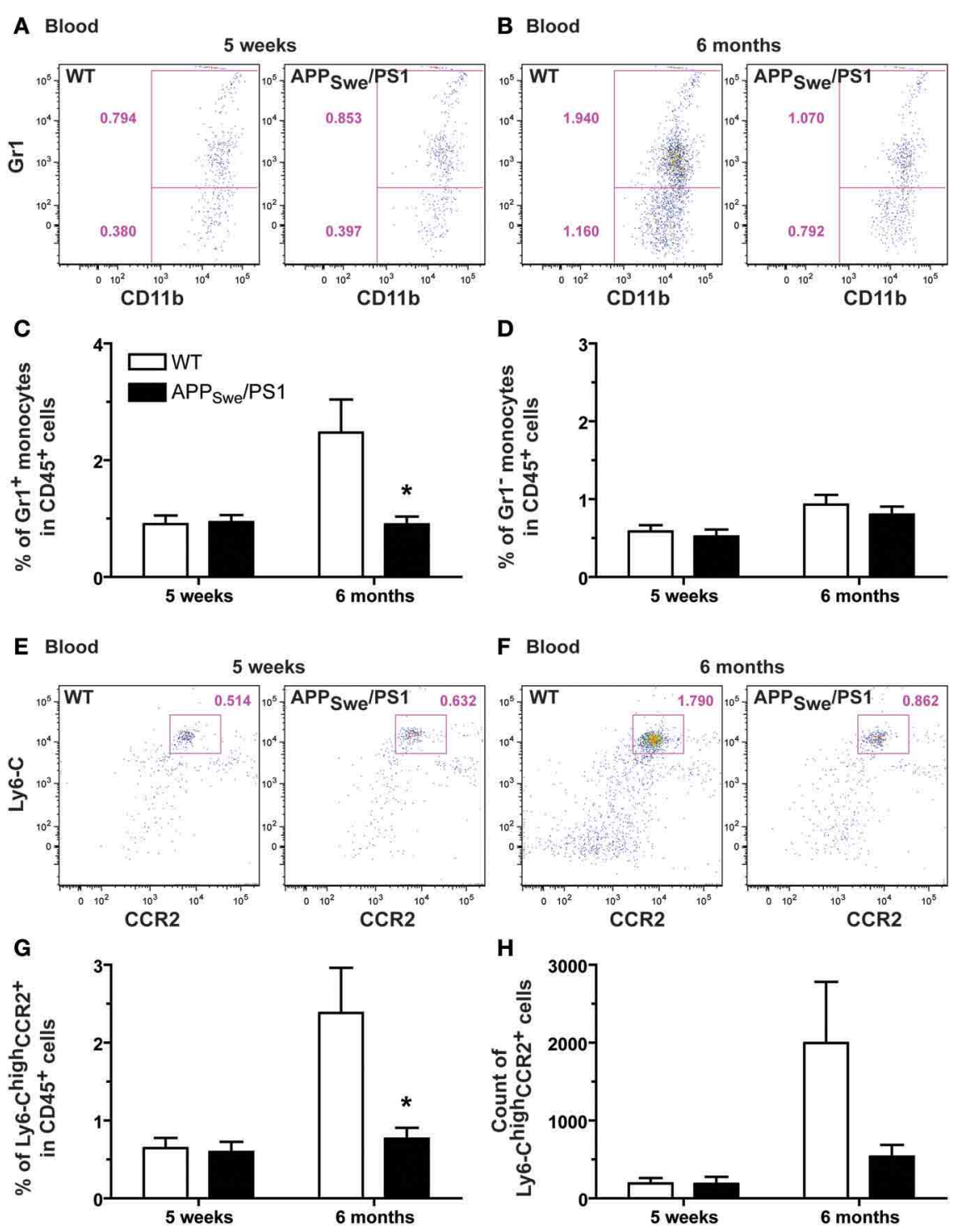

FIGURE 6 | Defective production of $\mathrm{Gr}^{1+}{ }^{+}$-y6-C ${ }^{\text {high }} \mathrm{CCR}^{+}$monocytes in 6-month-old APP swe $/$ PS1 mice. $\mathrm{Gr}^{+}{ }^{+} \mathrm{Ly}_{6} \mathrm{CC}^{\mathrm{high}} \mathrm{CCR} 2^{+}$monocytes were quantified by FACS analysis in the blood of WT and APP Swe $_{\text {PS1 } 1 \text { mice at } 5}$ weeks and 6 months of age. Monocytes were determined by the presence of $\mathrm{CD} 11 \mathrm{~b}$ and CD115. Different subsets of monocytes were characterized using Gr1, Ly6-C, and CCR2 antibodies. At 5 weeks of age, WT and APP Swe/PS1 mice exhibited similar levels of $\mathrm{Gr} 1^{+}\left(\mathbf{A}\right.$ and $\mathbf{C}$ ) and $\mathrm{Gr}^{-}$monocytes ( $\mathbf{A}$ and D). A marked increase in the population of $\mathrm{Gr}^{+}$monocytes was found in the

bloodstream of 6-month-old WT mice, but this phenomenon was totally prevented in APP swe $/ P S 1$ mice (B and $\mathbf{C}$ ). Although these mice failed to exhibit such increase in $\mathrm{Gr}^{+}{ }^{+}$monocytes, they had similar number of blood $\mathrm{Gr}^{-}{ }^{-}$monocytes when compared to WT animals (B and $\left.\mathbf{D}\right)$. The low frequency of $\mathrm{Gr} 1^{+}{ }^{-}$by-Chigh $C C R 2^{+}$monocytes was confirmed in 6-month-old $\mathrm{APP}_{\text {swe }} / \mathrm{PS} 1$ mice using more specific markers of the $\mathrm{Gr} 1^{+}$monocyte (e.g. Ly6-C and CCR2) (E-H). Results are expressed as the Mean \pm SEM; $n=7-8$; Student's $t$-test; ${ }^{*} p<0.05 ; *$ vs. WT at the same age.

Down-regulated expression of these genes has a clear impact on synaptic plasticity processes underlying long-term potentiation and memory in AD. This decrease of synaptic genes can be explained by the accumulation of soluble $A \beta$ since hippocampus of 6-month-old $\mathrm{APP}_{\text {Swe }} / \mathrm{PS} 1$ mice had elevated levels of both extracellular and intracellular $A \beta$. Both intra- and extracellular $\mathrm{A} \beta$ has the ability to affect expression of learning related genes (Wegenast-Braun et al., 2009). A decline in Arc and Egrl expression levels was correlated with the occurrence of cognitive impairment during aging (Blalock et al., 2003) and in transgenic mice carrying genes responsible for $\mathrm{AD}$ (Dickey et al., 2003, 2004). A $\beta$ oligomers can inhibit BDNF-induced Arc expression in culture cortical neurons (Wang et al., 2006; Echeverria et al., 2007), an effect modulated NMDA activity (Shankar et al., 2007). Because these genes are well-known to interact together, their low expression levels together with $A \beta$ accumulation may explain the progressive cognitive decline of $\mathrm{APP}_{\text {Swe }} / \mathrm{PS} 1$ mice.

This accumulation of soluble $A \beta$ could result of an enhanced production, a reduced degradation and/or a disrupted clearance. 


\section{A Bone marrow}
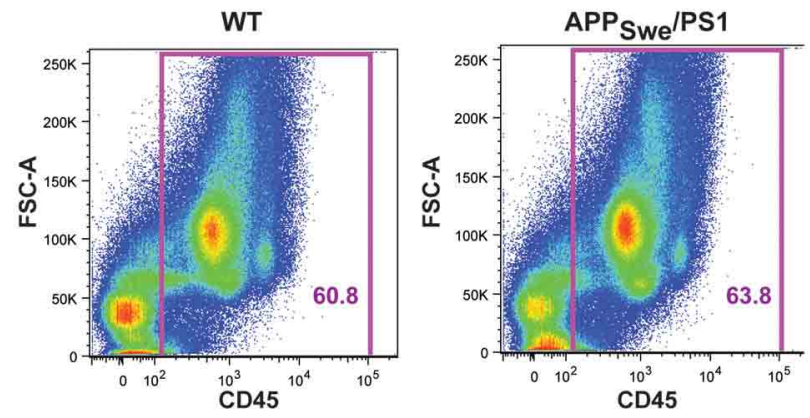

B
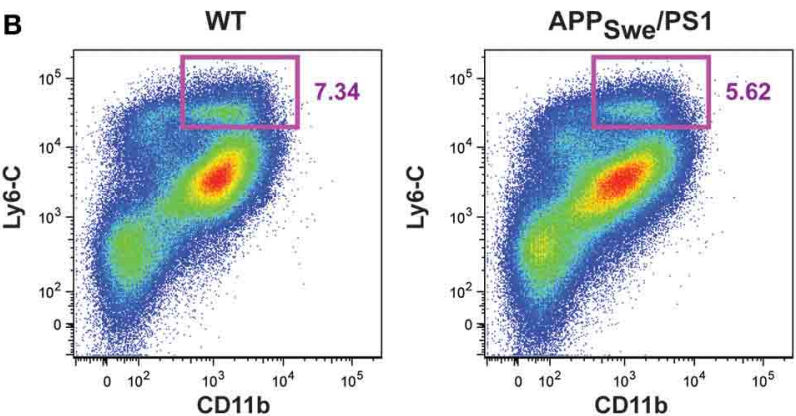

FIGURE $7 \mid \mathrm{Gr} 1^{+}$Ly6-C $^{\text {high }}$ CCR2 $^{+}$monocyte frequency is diminished in the bone marrow of 6-month-old APP Swe $_{\text {/PS1 mice. Leukocytes and }}$ Gr1 ${ }^{+}$Ly6-C $^{\text {high }} \mathrm{CCR}^{+}{ }^{+}$monocytes were quantified by FACS analysis in the bone marrow of WT and APP swe /PS1 mice at 6 months of age. The leukocyte population was assessed using the CD45 marker. At 6 months of age, WT and APP Swe/PS1 mice exhibited similar levels of leukocytes (A).
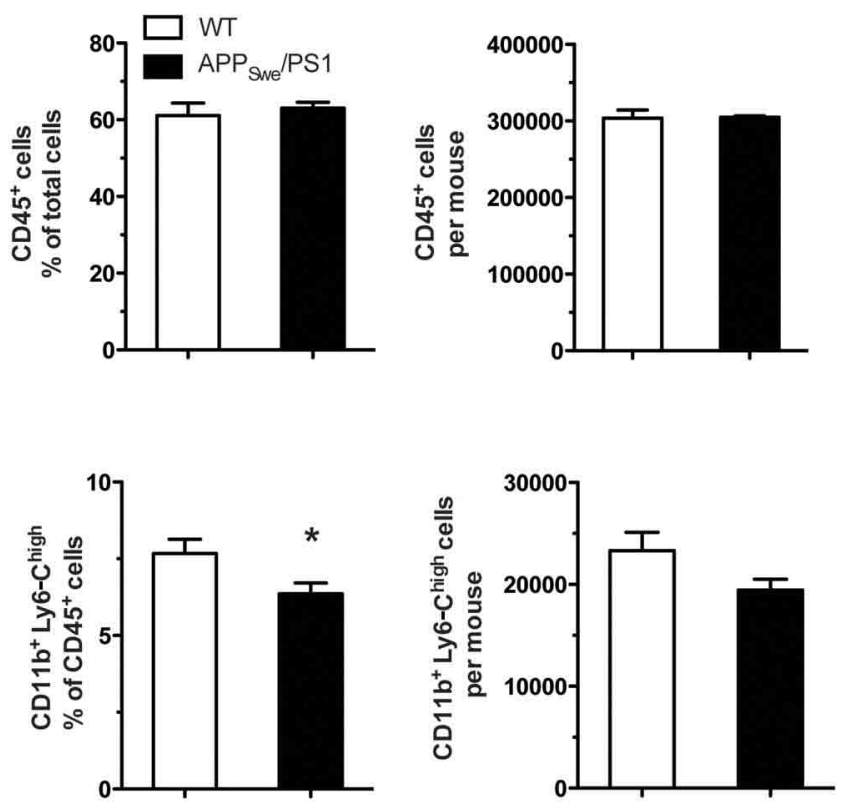

A major phenomenon in $\mathrm{AD}$ is the inability of mononuclear phagocytes to clear $A \beta$. Indeed, transplantation of competent CCR2 hematopoietic stem cells is able to counteract amyloid pathology and to restore mnesic capacity in 6-month-old $\mathrm{APP}_{\text {Swe }} / \mathrm{PS} 1$ and $\mathrm{APP}_{\text {Swe }} / \mathrm{PS} 1 / \mathrm{CCR} 2^{-/-}$mice (Naert and Rivest, 2012). In addition, CCR2 gene delivery in cells of the bone marrow restored the memory and learning capacities of 6-month-old $\mathrm{APP}_{\text {Swe }} / \mathrm{PS} 1$ mice (Naert and Rivest, 2012), suggesting strongly that there is dysfunctional CCR2 system in the bone marrow of $\mathrm{APP}_{\mathrm{Swe}} / \mathrm{PS} 1$ mice. For the first time we demonstrated that 6-month-old $\mathrm{APP}_{\text {Swe }} / \mathrm{PS} 1$ mice exhibited in the bloodstream a significant reduction of monocyte frequency, resulting of monocytopenia in the $\mathrm{CX}_{3} \mathrm{CR} 1^{\text {low }} \mathrm{Ly6}-\mathrm{C}^{\text {high }} \mathrm{Gr} 1^{+} \mathrm{CCR} 2^{+}$subset. As we have previously observed at the age of 3-4 months (Michaud et al., 2011; Naert and Rivest, 2012), 5-week-old WT and $\mathrm{APP}_{\text {Swe }} / \mathrm{PS} 1$ mice exhibited similar monocyte frequency for both subsets. In addition, the $\mathrm{CX}_{3} \mathrm{CR} 1^{\text {high }} \mathrm{Ly6}^{-\mathrm{C}^{\text {low }} \mathrm{Gr} 1^{-} \mathrm{CCR} 2^{-}}$subset has similar frequency in 6-month-old $\mathrm{APP}_{\text {Swe }} / \mathrm{PS} 1$ mice than in 6-month-old WT mice and this at all ages studied (Michaud et al., 2011; Naert and Rivest, 2012). As we only observed an effect in one of the two-monocyte subsets and not in the whole monocyte population, a proper effect of the presence of APP transgene controlled by the prion promoter seems to be excluded, suggesting strongly a preferential effect of $A \beta$ on inflammatory monocytes.
Therefore, this reduced level of inflammatory monocytes in bloodstream seems to be CCR2-dependent and could be explained by a reduced egress of monocyte from the bone marrow to blood circulation. Indeed, one major function of CCR2 is to permit the migration of CCR2 ${ }^{+}$monocytes from bone marrow to the blood (Serbina and Pamer, 2006; Engel et al., 2008). In addition CCR2 mediates hematopoietic stem and progenitor cell trafficking to sites of inflammation and monocyte infiltration into brain (Izikson et al., 2000; Babcock et al., 2003; Si et al., 2010). As the ratio of $\mathrm{Gr}^{+} / \mathrm{Gr}^{-}$monocytes is significantly decreased in a context of $\mathrm{AD}$, less $\mathrm{CX}_{3} \mathrm{CR} 1^{\text {low }} \mathrm{Ly} 6-\mathrm{C}^{\text {high }} \mathrm{Gr} 1^{+} \mathrm{CCR} 2^{+}$monocytes are available to clear $\mathrm{A} \beta$ in the bloodstream but also to be recruited into brain to remove brain $A \beta$. This expansion of the non-classical $\mathrm{CD} 14^{+} \mathrm{CD} 16^{+}$subtype-counterpart of mouse $\mathrm{CX}_{3} \mathrm{CR} 1^{\text {high }}$ Ly6-C ${ }^{\text {low }} \mathrm{Gr} 1^{-} \mathrm{CCR} 2^{-}$- has been already observed in aged healthy adult (Seidler et al., 2010). In addition their phenotype changes dependent on age, resulting in lower expression of activation markers and chemokine receptors (Seidler et al., 2010). The CD $14^{++} \mathrm{CD} 16^{-}$monocytes display some variation in CCR2 expression, with highest levels in healthy adults at the age between 30 and 50 years and a significant decreased expression in adults older than 50 years (Seidler et al., 2010). Although alterations in peripheral immune cells are also reported in patients with $\mathrm{AD}$, examination of peripheral leukocytes-principally lymphocytes and monocytes-by different groups revealed conflicting 


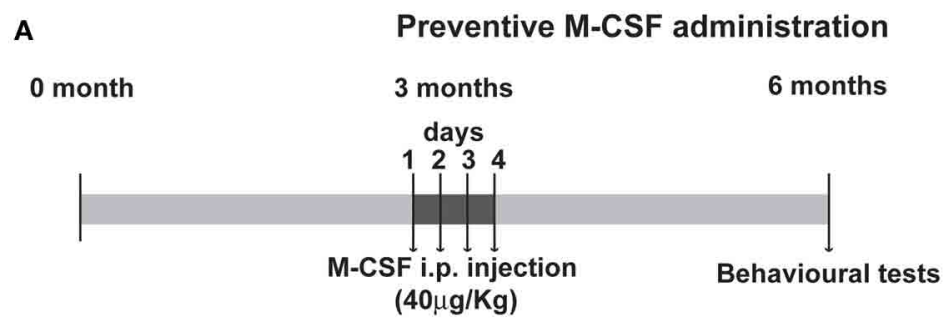

B

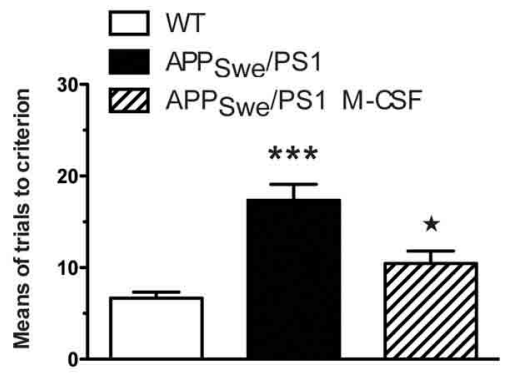

C

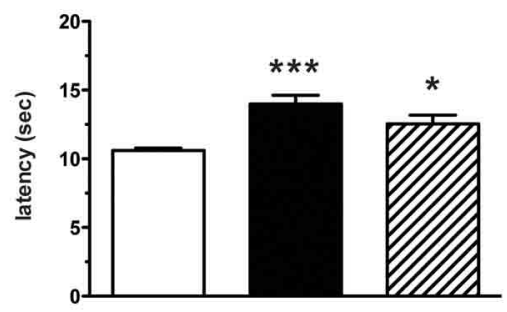

D

Curative M-CSF administration
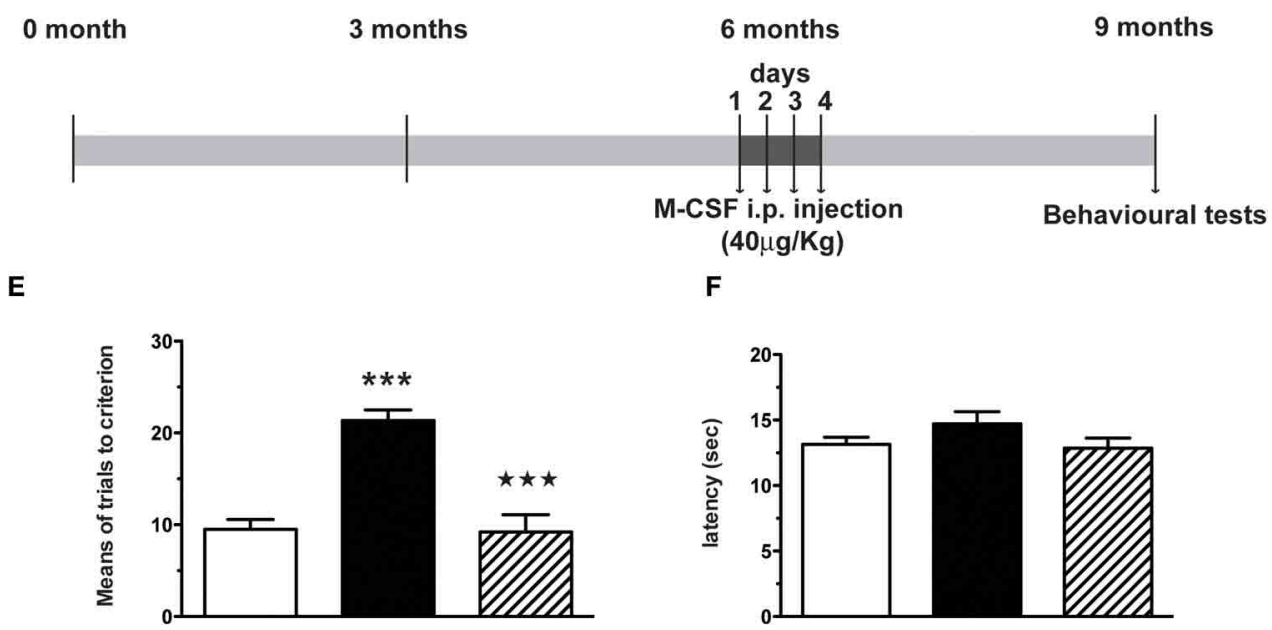

FIGURE 8| Short M-CSF treatment is able to prevent and to rescue learning and memory impairment in APP $_{\text {Swe }} /$ PS1 mice. APP swe $/ P S 1$ mice received M-CSF treatment during 4 days $(40 \mu \mathrm{g} / \mathrm{Kg} /$ day) before (at 3 months) or after occurrence of mnesic deficit (at 6 months) and were tested in the $T$ water-maze paradigm 3 months later $(\mathbf{A})$. The numbers of trials ( $\mathbf{B}$ and $\mathbf{E}$ ) and the latency ( $\mathbf{C}$ and $\mathbf{F}$ ) to accomplish the task were determined during reversal learning phase. M-CSF treatment prevented spatial memory decline generally observed in 6-month-old APPswe/PS1 mice (B). In addition, M-CSF treatment after occurrence of mnesic impairment (at 6 months) (D) rescued spatial memory in 9-month-old $\mathrm{APP}_{\text {Swe }} / \mathrm{PS} 1$ mice (E). Results are expressed as the Mean $\pm \mathrm{SEM}$; $n=8-16$ per group; * $p<0.05$ and ${ }^{* * *} p<0.001$; * vs. WT, * vs. $\mathrm{APP}_{\text {Swe }} / \mathrm{PS} 1$ mice. (One-way ANOVA was performed in each genotype using Bonferroni or Tamhane's post-hoc test). results and currently there is no general consensus on the modifications of leukocytes in $\mathrm{AD}$ patients. By contrast, a recent analysis of peripheral blood mononuclear cell (PBMC) in a large older human population revealed increased of CCR2 levels associated with lower Mini Mental State Examination (MMSE) scores (Harries et al., 2012). These data corroborates the increased CCR2 expression in PBMC of AD patients (Reale et al., 2008; Pellicano et al., 2010). It is important to mention that CCR2 expression levels were only determined in lymphocytes (Reale et al., 2008; Pellicano et al., 2010). CCR2 expression is globally upregulated in $\mathrm{CD}^{+}$lymphocytes and down regulated in $\mathrm{CD}^{+}$lymphocytes (Reale et al., 2008). Unfortunately these studies have not investigated the CCR2 status in monocytes of AD patients neither that they did perform the distribution of each monocyte subset. The global increase of CCR2 expression levels in PBMC could then reflect CCR2 upregulation in lymphocyte, considering the 

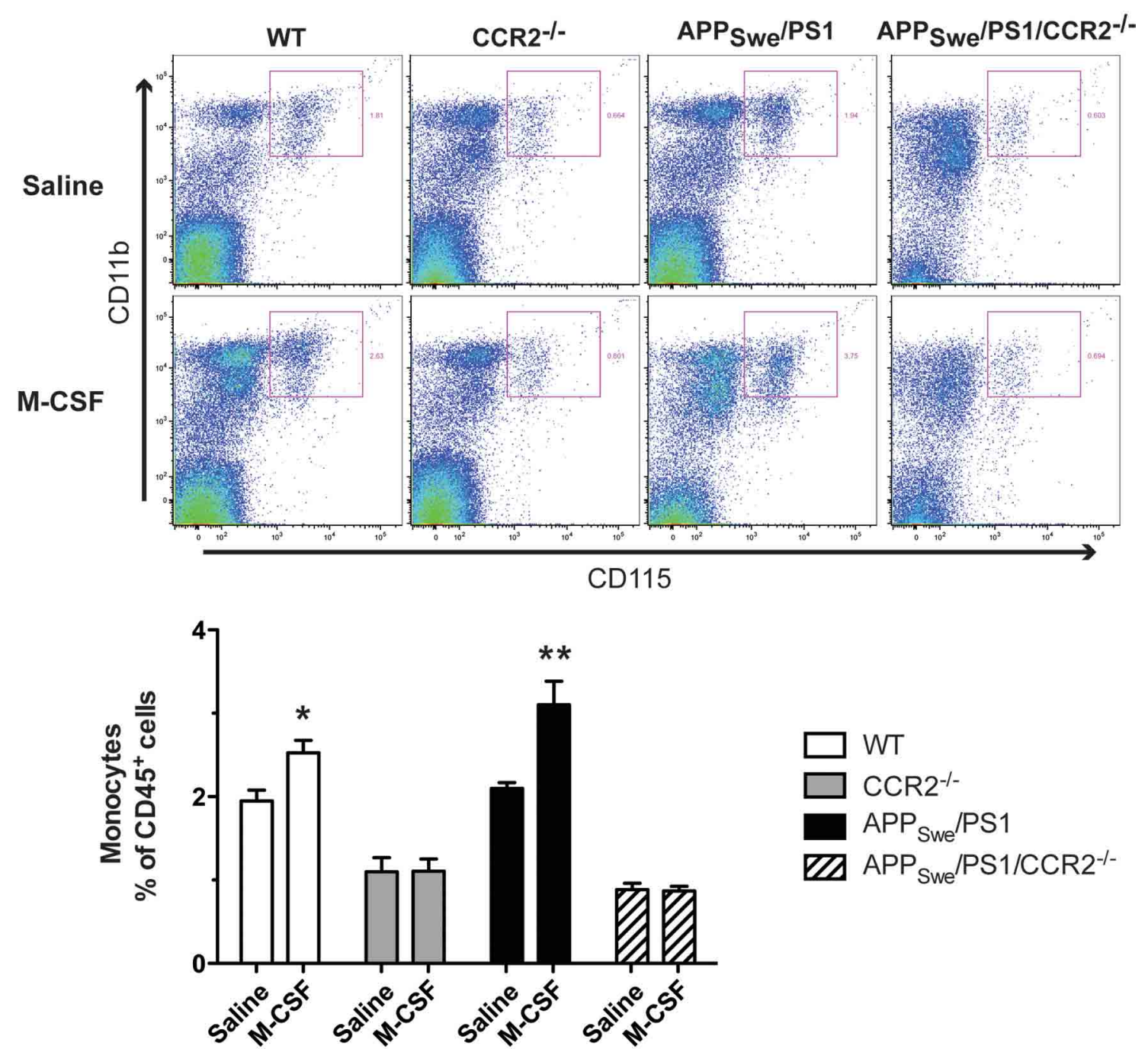

FIGURE 9 | Short M-CSF treatment increases monocyte frequency in

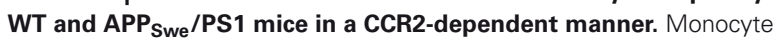
frequency was determined by FACS analysis within the population of CD45+ cells using the CD11b and CD115 markers in WT, CCR2 $2^{-/-}$, APP swe $/ P S 1$, and $\mathrm{APP}_{\text {Swe }} / \mathrm{PS} 1 / \mathrm{CCR} 2^{-/-}$mice. Mice received saline or M-CSF treatment during 4 days $(40 \mu \mathrm{g} / \mathrm{Kg} /$ day) at the age of 4 months and blood samples were analyzed $24 \mathrm{~h}$ after the last injection. M-CSF treatment increased the frequency of monocytes $\left(C D 11 b^{+}\right.$CD $\left.115^{+}\right)$in both WT and APP swe/PS1 groups of mice. In contrast, monocyte frequency remained very low in $\mathrm{CCR}^{-/-}$and $\mathrm{APP}_{\text {Swe }} / \mathrm{PS} 1 / \mathrm{CCR} 2^{-/-}$mice treated or not with the cytokine. Results are expressed as the Mean \pm SEM; $n=5-8$; Student's $t$-test; ${ }^{*} p<0.05 ;{ }^{* *} p<0.01 ;{ }^{*}$ vs. saline treatment in the same genotype. prevalence of lymphocytes in human PBMC. More work has to be done to better understand the role of CCR2 in monocytic cells in $\mathrm{AD}$ patients.

Here analysis of CCR2 levels in FACS studies did not reveal a different intensity in monocytes between 6-month-old WT and $\mathrm{APP}_{\text {Swe }} / \mathrm{PS} 1$ mice (data not shown), suggesting that their low blood frequencies may be caused by a decreased production or their retention in bone marrow as observed in CCR2-deficient mice (Serbina and Pamer, 2006). We found a decreased frequency of Ly6-C $\mathrm{C}^{\text {high }}$ monocytes in the bone marrow of 6-month-old $\mathrm{APP}_{\text {Swe }} / \mathrm{PS} 1$ mice, suggesting a deficient production of Ly6$\mathrm{C}^{\text {high }}$ monocytes. These data support the concept that alteration in the numbers, phenotype, and functionality of mononuclear cells occurred in $\mathrm{AD}$. Indeed monocytes of $\mathrm{AD}$ patients exhibit poor in vitro differentiation, poor phagocytic properties for and undergo apoptosis after $\mathrm{A} \beta$ application (Fiala et al., 2005).

The development of blood monocytes is dependent on M-CSF (also known as Csf-1) (Auffray et al., 2009). In mice deficient in M-CSF and its receptor M-CSFR (CD115), monocyte frequency is drastically reduced in bloodstream (Ryan et al., 2001; Dai et al., 2002). M-CSF transgene expression rescues the differentiation of monocytes in M-CSF-deficient mice (Ryan et al., 2001). It is very interesting to note that a short systemic treatment with M-CSF was able to prevent and rescue cognitive impairments in $\mathrm{APP}_{\text {Swe }} / \mathrm{PS} 1$ mice and reestablish the circulating level of monocytes. The defect in mononuclear cells observed in $\mathrm{APP}_{\text {Swe }} / \mathrm{PS} 1$ mice is therefore not dependent on CD115, since $\mathrm{M}$-CSF treatment increased monocyte frequency in 4-month-old 
$\mathrm{APP}_{\text {Swe }} / \mathrm{PS} 1$ mice in levels comparable to those of age-matched WT mice. M-CSF treatment failed to increase monocyte population in $\mathrm{CCR} 2^{-/-}$and $\mathrm{APP}_{\text {Swe }} / \mathrm{PS} 1 / \mathrm{CCR} 2^{-/-}$mice, suggesting a CCR2-dependent mechanism of M-CSF. These data suggest that expression of CCR2 is low in the bone marrow of $\mathrm{APP}_{\text {Swe }} / \mathrm{PS} 1$ mice or Ly6-C $\mathrm{C}^{\text {high }}$ monocyte differentiation is impaired, and this may explain the low frequency of inflammatory monocytes, but these cells still have the ability to respond in presence of hematopoietic cytokines. These data obtained after 4-day M-CSF treatment confirm our previous results observed after a long $\mathrm{M}$-CSF treatment in $\mathrm{APP}_{\text {Swe }} / \mathrm{PS} 1$ mice (Boissonneault et al., 2009). Indeed a long M-CSF treatment prevented and restored cognitive deficits, but $\mathrm{M}$-CSF also increased the number of microglia and decreased the number of $A \beta$ deposits (Boissonneault et al., 2009), certainly by enhancing $A \beta$ phagocytosis by microglia, a known effect of M-CSF (Mitrasinovic and Murphy, 2003; Mitrasinovic et al., 2003; Majumdar et al., 2007). Besides, other hematopoietic cytokines, such as G-CSF or GM-CSF, had been shown to have beneficial effects in $\mathrm{AD}$ mouse model (Tsai et al., 2007; Volmar et al., 2008; SanchezRamos et al., 2009; Boyd et al., 2010; Jiang et al., 2010; Li et al., 2011). More interestingly, G-CSF decreased both brain A $\beta$ deposition and soluble $A \beta$ accumulation by activating directly microglia and by enhancing the recruitment of BMDM and also restored synaptophysin expression in APP mice (Sanchez-Ramos et al., 2009). Despite a general beneficial therapeutic effect of most of hematopoietic cytokines, M-CSF seems to be a preferential target in $\mathrm{AD}$ as $\mathrm{M}-\mathrm{CSF}$ acts specifically on bone marrow to produce the

\section{REFERENCES}

Ango, F., Pin, J. P., Tu, J. C., Xiao, B., Worley, P. F., Bockaert, J., et al. (2000). Dendritic and axonal targeting of type 5 metabotropic glutamate receptor is regulated by homerl proteins and neuronal excitation. J. Neurosci. 20, 8710-8716.

Auffray, C., Sieweke, M. H., and Geissmann, F. (2009). Blood monocytes: development, heterogeneity, and relationship with dendritic cells. Annu. Rev. Immunol. 27, 669-692.

Babcock, A. A., Kuziel, W. A., Rivest, S., and Owens, T. (2003). Chemokine expression by glial cells directs leukocytes to sites of axonal injury in the CNS. J. Neurosci. 23, 7922-7930.

Blalock, E. M., Chen, K. C., Sharrow, K., Herman, J. P., Porter, N. M., Foster, T. C., et al. (2003). Gene microarrays in hippocampal aging: statistical profiling identifies novel processes correlated with cognitive impairment. J. Neurosci. 23, 3807-3819.

Bloomer, W. A., VanDongen, H. M., and VanDongen, A. M. (2008). Arc/Arg3.1 translation is controlled by convergent N-methyl-Daspartate and Gs-coupled receptor signaling pathways. J. Biol. Chem. 283, 582-592.

Boggs, D., Patrene, K., and Steinberg, H. (1986). Aging and hematopoiesis. VI. Neutrophilia and other leukocyte changes in aged mice. Exp. Hematol. 14, 372-379.

Boissonneault, V., Filali, M., Lessard, M., Relton, J., Wong, G., and Rivest, S. (2009). Powerful beneficial effects of macrophage colonystimulating factor on beta-amyloid deposition and cognitive impairment in Alzheimer's disease. Brain 132, 1078-1092.

Bolmont, T., Haiss, F., Eicke, D., Radde, R., Mathis, C. A., Klunk, W. E., et al. (2008). Dynamics of the microglial/amyloid interaction indicate a role in plaque maintenance. J. Neurosci. 28, 4283-4292.

Boyd, T. D., Bennett, S. P., Mori, T., Governatori, N., Runfeldt, M., Norden, M., et al. (2010). GM-CSF upregulated in rheumatoid arthritis reverses cognitive impairment and amyloidosis in Alzheimer mice. J. Alzheimers Dis. 21, 507-518.

Cheng, I. H., Scearce-Levie, K., Legleiter, J., Palop, J. J., Gerstein, H., Bien-Ly, N., et al. (2007). Accelerating amyloid-beta fibrillization reduces oligomer levels and

monocytes, the microglial precursor cells. Although $\mathrm{APP}_{\text {Swe }} / \mathrm{PS} 1$ mice exhibited with aging a significant monocytopenia, their bone marrow cells are still able to respond properly to M-CSF treatment, suggesting a functional CSF1-R. Monocyte development and differentiation (Auffray et al., 2009) and Ly6-Chigh monocyte extravasation (Tagliani et al., 2011) are dependent on M-CSF.

A defect in the monocytopoiesis was found in a mouse model of $\mathrm{AD}$, resulting in a decrease of $\mathrm{CX}_{3} \mathrm{CR} 1^{\text {low }} \mathrm{Ly6}$ $\mathrm{C}^{\text {high }} \mathrm{Gr}^{+}{ }^{+} \mathrm{CCR} 2^{+}$subset of monocytes. This phenomenon may be a key mechansism for the accumulation of $A \beta$, synaptic disruption, deficit in neurotrophic factors, and decline of memory and learning functions. Stimulating the production of $\mathrm{CCR} 2^{+}$monocytes with M-CSF should be seriously considered for clinical trials in early diagnosed $\mathrm{AD}$ patients.

\section{ACKNOWLEDGMENTS}

The Canadian Institutes in Health Research (CIHR) and Neuroscience Canada (Brain Repair Program) supported this research. Gaëlle Naert was supported by a postdoctoral Fellowship from the Alzheimer Society of Canada. Serge Rivest holds a Canadian Research Chair in Neuroimmunology. We acknowledge the contribution of Dr. Mohammed Filali, Ms. Martine Lessard, Mr. Paul Préfontaine, and Ms. Marie-Michèle Plante for technical help. We are grateful to Dr. Matthias Mack (Universitätsklinikum Regensburg Innere Medizin II/Nephrologie-Transplantation, Regensburg, Germany) for the generous gift of the anti-CCR2 antibody (Ab MC-21).

functional deficits in Alzheimer disease mouse models. J. Biol. Chem. 282, 23818-23828.

Clayton, D. A., Mesches, M. H. Alvarez, E., Bickford, P. C., and Browning, M. D. (2002). A hippocampal NR2B deficit can mimic age-related changes in long-term potentiation and spatial learning in the Fischer 344 rat. J. Neurosci. 22, 3628-3637.

Cleary, J. P., Walsh, D. M., Hofmeister, J. J., Shankar, G. M., Kuskowski, M. A., Selkoe, D. J., et al. (2005) Natural oligomers of the amyloidbeta protein specifically disrupt cognitive function. Nat. Neurosci. 8, 79-84.

Coleman, P. D., and Yao, P. J. (2003) Synaptic slaughter in Alzheimer's disease. Neurobiol. Aging 24, 1023-1027.

Connor, B., Young, D., Yan, Q., Faull, R. L., Synek, B., and Dragunow, M. (1997). Brain-derived neurotrophic factor is reduced in Alzheimer's disease. Brain Res. 49, 71-81.

Dai, X. M., Ryan, G. R., Hapel, A J., Dominguez, M. G., Russell R. G., Kapp, S., et al. (2002). Targeted disruption of the mouse colony-stimulating factor 1 receptor gene results in osteopetrosis, mononuclear phagocyte deficiency, increased primitive progenitor cell frequencies, and reproductive defects. Blood 99, 111-120.

Dickey, C. A., Gordon, M. N., Mason, J. E., Wilson, N. J., Diamond, D. M., Guzowski, J. F., et al. (2004). Amyloid suppresses induction of genes critical for memory consolidation in APP + PS1 transgenic mice. J. Neurochem. 88, 434-442.

Dickey, C. A., Loring, J. F., Montgomery, J., Gordon, M. N., Eastman, P. S., and Morgan, D. (2003). Selectively reduced expression of synaptic plasticityrelated genes in amyloid precursor protein + presenilin-1 transgenic mice. J. Neurosci. 23, 5219-5226.

Dickson, D. W., Farlo, J., Davies, P., Crystal, H., Fuld, P., and Yen, S. H. (1988). Alzheimer's disease. A double-labeling immunohistochemical study of senile plaques. Am. J. Pathol. 132, 86-101.

Echeverria, V., Berman, D. E., and Arancio, O. (2007). Oligomers of beta-amyloid peptide inhibit BDNF-induced arc expression in cultured cortical Neurons. Curr. Alzheimer Res. 4, 518-521.

El Khoury, J., Toft, M., Hickman, S. E., Means, T. K., Terada, K., 
Geula, C., et al. (2007). Ccr2 deficiency impairs microglial accumulation and accelerates progression of Alzheimer-like disease. Nat. Med. 13, 432-438.

Engel, D. R., Maurer, J., Tittel, A. P., Weisheit, C., Cavlar, T., Schumak, B., et al. (2008). CCR2 mediates homeostatic and inflammatory release of Gr1(high) monocytes from the bone marrow, but is dispensable for bladder infiltration in bacterial urinary tract infection. J. Immunol. 181, 5579-5586.

Fiala, M., Lin, J., Ringman, J., KermaniArab, V., Tsao, G., Patel, A., et al. (2005). Ineffective phagocytosis of amyloid-beta by macrophages of Alzheimer's disease patients. J. Alzheimers Dis. 7, 221-232. discussion: 255-262.

Geissmann, F., Jung, S., and Littman, D. R. (2003). Blood monocytes consist of two principal subsets with distinct migratory properties. Immunity 19, 71-82.

Getts, D. R., Terry, R. L., Getts, M. T., Muller, M., Rana, S., Shrestha, B., et al. (2008). Ly6c+ "inflammatory monocytes" are microglial precursors recruited in a pathogenic manner in West Nile virus encephalitis. J. Exp. Med. 205, 2319-2337.

Grammas, P., and Ovase, R. (2001). Inflammatory factors are elevated in brain microvessels in Alzheimer's disease. Neurobiol. Aging 22, 837-842.

Haass, C., and Selkoe, D. J. (2007). Soluble protein oligomers in neurodegeneration: lessons from the Alzheimer's amyloid beta-peptide. Nat. Rev. 8, 101-112.

Haga, S., Akai, K., and Ishii, T. (1989). Demonstration of microglial cells in and around senile (neuritic) plaques in the Alzheimer brain. An immunohistochemical study using a novel monoclonal antibody. Acta Neuropathol. 77, 569-575.

Harries, L. W., Bradley-Smith, R. M., Llewellyn, D. J., Pilling, L. C., Fellows, A., Henley, W., et al. (2012). Leukocyte CCR2 expression is associated with mini-mental state examination score in older adults. Rejuvenation Res. 15, 395-404.

Hickman, S. E., Allison, E. K., and El Khoury, J. (2008). Microglial dysfunction and defective betaamyloid clearance pathways in aging Alzheimer's disease mice. J. Neurosci. 28, 8354-8360.

Ishizuka, K., Kimura, T., Igata-yi, R., Katsuragi, S., Takamatsu, J., and Miyakawa, T. (1997). Identification of monocyte chemoattractant protein-1 in senile plaques and reactive microglia of Alzheimer's disease. Psychiatry Clin. Neurosci. 51, 135-138.

Izikson, L., Klein, R. S., Charo, I. F., Weiner, H. L., and Luster, A. D. (2000). Resistance to experimental autoimmune encephalomyelitis in mice lacking the CC chemokine receptor (CCR)2. J. Exp. Med. 192, 1075-1080.

Jiang, H., Liu, C. X., Feng, J. B., Wang, P., Zhao, C. P., Xie, Z. H., et al. (2010). Granulocyte colonystimulating factor attenuates chronic neuroinflammation in the brain of amyloid precursor protein transgenic mice: an Alzheimer's disease mouse model. J. Int. Med. Res. 38, 1305-1312.

Kawarabayashi, T., Shoji, M., Younkin, L. H., Wen-Lang, L., Dickson, D. W., Murakami, T., et al. (2004). Dimeric amyloid beta protein rapidly accumulates in lipid rafts followed by apolipoprotein $\mathrm{E}$ and phosphorylated tau accumulation in the Tg2576 mouse model of Alzheimer's disease. J. Neurosci. 24, 3801-3809.

Kemppainen, S., Rantamäki, T., Jerónimo-Santos, A., Lavasseur, G., Autio, H., Karpova, N., et al. (2012). Impaired TrkB receptor signaling contributes to memory impairment in APP/PS1 mice. Neurobiol. Aging 33, 1122.e23-1122.e39.

Laflamme, N., Lacroix, S., and Rivest, S. (1999). An essential role of interleukin-1beta in mediating NFkappaB activity and COX-2 transcription in cells of the blood-brain barrier in response to a systemic and localized inflammation but not during endotoxemia. J. Neurosci. 19, 10923-10930.

Laflamme, N., and Rivest, S. (2001). Toll-like receptor 4 , the missing link of the cerebral innate immune response triggered by circulating gram-negative bacterial cell wall components. FASEB J. 15, 155-163.

Larson, M. E., and Lesné, S. E. (2011). Soluble Abeta oligomer production and toxicity. J. Neurochem. 120(Suppl. 1), 125-139.

Lee, S., Varvel, N. H., Konerth, M. E., Xu, G., Cardona, A. E., Ransohoff, R. M., et al. (2010). CX3CR1 deficiency alters microglial activation and reduces beta-amyloid deposition in two Alzheimer's disease mouse models. Am. J. Pathol. 177, 2549-2562.

Lesné, S., Koh, M. T., Kotilinek, L., Kayed, R., Glabe, C. G., Yang, A., et al. (2006). A specific amyloidbeta protein assembly in the brain impairs memory. Nature 440, 352-357.
Lesné, S., Kotilinek, L., and Ashe, K. H. (2008). Plaque-bearing mice with reduced levels of oligomeric amyloid-beta assemblies have intact memory function. Neuroscience 151, 745-749.

Li, B., Gonzalez-Toledo, M. E., Piao, C. S., Gu, A., Kelley, R. E., and Zhao, L. R. (2011). Stem cell factor and granulocyte colony-stimulating factor reduce beta-amyloid deposits in the brains of APP/PS1 transgenic mice. Alzheimers Res. Ther. 3, 8 .

Li, W., and Keifer, J. (2009). BDNFinduced synaptic delivery of AMPAR subunits is differentially dependent on NMDA receptors and requires ERK. Neurobiol. Learn. Mem. 91, 243-249.

Liu, Z., Condello, C., Schain, A., Harb, R., and Grutzendler, J. (2010). CX3CR1 in microglia regulates brain amyloid deposition through selective protofibrillar amyloidbeta phagocytosis. J. Neurosci. 30, 17091-17101.

Lue, L. F., Kuo, Y. M., Roher, A. E., Brachova, L., Shen, Y., Sue, L., et al. (1999). Soluble amyloid beta peptide concentration as a predictor of synaptic change in Alzheimer's disease. Am. J. Pathol. 155, 853-862.

Ma, T., and Klann, E. (2011). Amyloid beta: linking synaptic plasticity failure to memory disruption in Alzheimer's disease. J. Neurochem. 120(Suppl. 1), 140-148.

Mack, M., Cihak, J., Simonis, C. Luckow, B., Proudfoot, A. E., Plachy, J., et al. (2001). Expression and characterization of the chemokine receptors CCR2 and CCR5 in mice. J. Immunol. 166, 4697-4704.

Majumdar, A., Cruz, D., Asamoah, N., Buxbaum, A., Sohar, I., Lobel, P., et al. (2007). Activation of microglia acidifies lysosomes and leads to degradation of Alzheimer amyloid fibrils. Mol. Biol. Cell 18, 1490-1496.

Malinow, R., and Malenka, R. C. (2002). AMPA receptor trafficking and synaptic plasticity. Annu. Rev Neurosci. 25, 103-126.

Malm, T. M., Koistinaho, M., Parepalo, M., Vatanen, T., Ooka, A., Karlsson, S., et al. (2005). Bone-marrowderived cells contribute to the recruitment of microglial cells in response to beta-amyloid deposition in APP/PS1 double transgenic Alzheimer mice. Neurobiol. Dis. 18, 134-142.

Mandrekar, S., Jiang, Q., Lee, C. Y., Koenigsknecht-Talboo, J., Holtzman, D. M., and Landreth, G. E. (2009). Microglia mediate the clearance of soluble Abeta through fluid phase macropinocytosis. J. Neurosci. 29, 4252-4262.
McLean, C. A., Cherny, R. A., Fraser, F. W., Fuller, S. J., Smith, M. J. Beyreuther, K., et al. (1999). Soluble pool of Abeta amyloid as a determinant of severity of neurodegeneration in Alzheimer's disease. Ann. Neurol. 46, 860-866.

Michaud, J. P., Richard, K. L., and Rivest, S. (2011). MyD88-adaptor protein acts as a preventive mechanism for memory deficits in a mouse model of Alzheimer's disease. Mol. Neurodegener. 6, 5.

Mildner, A., Schlevogt, B., Kierdorf, K., Bottcher, C., Erny, D., Kummer, M. P., et al. (2011). Distinct and nonredundant roles of microglia and myeloid subsets in mouse models of Alzheimer's disease. J. Neurosci. 31, 11159-11171.

Mildner, A., Schmidt, H., Nitsche, M., Merkler, D., Hanisch, U. K., Mack, M., et al. (2007). Microglia in the adult brain arise from Ly-6ChiCCR2+ monocytes only under defined host conditions. Nat. Neurosci. 10, 1544-1553.

Mitrasinovic, O. M., and Murphy, G. M. Jr. (2003). Microglial overexpression of the M-CSF receptor augments phagocytosis of opsonized Abeta. Neurobiol. Aging 24, 807-815.

Mitrasinovic, O. M., Vincent, V. A., Simsek, D., and Murphy, G. M. Jr. (2003). Macrophage colony stimulating factor promotes phagocytosis by murine microglia. Neurosci. Lett. 344, 185-188.

Nadeau, S., and Rivest, S. (2000). Role of microglial-derived tumor necrosis factor in mediating CD14 transcription and nuclear factor kappa B activity in the brain during endotoxemia. J. Neurosci. 20, 3456-3468.

Naert, G., Laflamme, N., and Rivest, S. (2009). Toll-like receptor 2-independent and MyD88dependent gene expression in the mouse brain. J. Innate Immun. 1 , 480-493.

Naert, G., and Rivest, S. (2011a). CC chemokine receptor 2 deficiency aggravates cognitive impairments and amyloid pathology in a transgenic mouse model of Alzheimer's disease. J. Neurosci. 31, 6208-6220.

Naert, G., and Rivest, S. (2011b). The role of microglial cell subsets in Alzheimer's disease. Curr. Alzheimer Res. 8, 151-155.

Naert, G., and Rivest, S. (2012). Hematopoietic CC-chemokine receptor 2-(CCR2) competent cells are protective for the cognitive impairments and amyloid pathology in a transgenic mouse model of Alzheimer's disease. Mol. Med. 18, 297-313. 
Nagahara, A. H., Merrill, D. A., Coppola, G., Tsukada, S., Schroeder, B. E., Shaked, G. M., et al. (2009). Neuroprotective effects of brainderived neurotrophic factor in rodent and primate models of Alzheimer's disease. Nat. Med. 15, 331-337.

Naslund, J., Haroutunian, V., Mohs, R., Davis, K. L., Davies, P., Greengard, P., et al. (2000). Correlation between elevated levels of amyloid beta-peptide in the brain and cognitive decline. JAMA 283, 1571-1577.

Pellicano, M., Bulati, M., Buffa, S., Barbagallo, M., Di Prima, A., Misiano, G., et al. (2010). Systemic immune responses in Alzheimer's disease: in vitro mononuclear cell activation and cytokine production. J. Alzheimers Dis. 21, 181-192.

Perry, V. H., and Gordon, S. (1988). Macrophages and microglia in the nervous system. Trends Neurosci. 11, 273-277.

Reale, M., Iarlori, C., Feliciani, C., and Gambi, D. (2008). Peripheral chemokine receptors, their ligands, cytokines and Alzheimer's disease. J. Alzheimers Dis. 14, 147-159.

Richard, K. L., Filali, M., Prefontaine, P., and Rivest, S. (2008). Toll-like receptor 2 acts as a natural innate immune receptor to clear amyloid beta 1-42 and delay the cognitive decline in a mouse model of Alzheimer's disease. J. Neurosci. 28, 5784-5793.

Ryan, G. R., Dai, X. M., Dominguez, M. G., Tong, W., Chuan, F., Chisholm, O., et al. (2001). Rescue of the colony-stimulating factor 1 (CSF-1)-nullizygous mouse (Csf1(op)/Csf1(op)) phenotype with a CSF-1 transgene and identification of sites of local CSF-1 synthesis. Blood 98, 74-84.

Saederup, N., Cardona, A. E., Croft, K., Mizutani, M., Cotleur, A. C., Tsou, C. L., et al. (2010). Selective chemokine receptor usage by central nervous system myeloid cells in CCR2-red fluorescent protein knock-in mice. PLoS ONE 5:e13693. doi: 10.1371/journal.pone.0013693

Sanchez-Ramos, J., Song, S., Sava, V., Catlow, B., Lin, X., Mori, T., et al. (2009). Granulocyte colony stimulating factor decreases brain amyloid burden and reverses cognitive impairment in Alzheimer's mice. Neuroscience 163, 55-72.

Seidler, S., Zimmermann, H. W., Bartneck, M., Trautwein, C., and Tacke, F. (2010). Age-dependent alterations of monocyte subsets and monocyte-related chemokine pathways in healthy adults. BMC Immunol. 11:30. doi: 10.1186/1471-2172-11-30

Selkoe, D. J. (2002). Alzheimer's disease is a synaptic failure. Science 298 , 789-791.

Serbina, N. V., and Pamer, E. G. (2006). Monocyte emigration from bone marrow during bacterial infection requires signals mediated by chemokine receptor CCR2. Nat. Immunol. 7, 311-317.

Shankar, G. M., Bloodgood, B. L., Townsend, M., Walsh, D. M., Selkoe, D. J., and Sabatini, B. L. (2007). Natural oligomers of the Alzheimer amyloid-beta protein induce reversible synapse loss by modulating an NMDA-type glutamate receptor-dependent signaling pathway. J. Neurosci. 27, 2866-2875.

Shankar, G. M., Li, S., Mehta, T. H., Garcia-Munoz, A., Shepardson, N. E., Smith, I., et al. (2008). Amyloidbeta protein dimers isolated directly from Alzheimer's brains impair synaptic plasticity and memory. Nat. Med. 14, 837-842.

Si, Y., Tsou, C. L., Croft, K., and Charo, I. F. (2010). CCR2 mediates hematopoietic stem and progenitor cell trafficking to sites of inflammation in mice. J. Clin. Invest. 120, 1192-1203.

Simard, A. R., and Rivest, S. (2004). Bone marrow stem cells have the ability to populate the entire central nervous system into fully differentiated parenchymal microglia. FASEB J. 18, 998-1000.

Simard, A. R., and Rivest, S. (2006) Neuroprotective properties of the innate immune system and bone marrow stem cells in Alzheimer's disease. Mol. Psychiatry 11, 327-335.

Simard, A. R., Soulet, D., Gowing, G., Julien, J. P., and Rivest, S. (2006). Bone marrow-derived microglia play a critical role in restricting senile plaque formation in Alzheimer's disease. Neuron 49 489-502.

Soulet, D., and Rivest, S. (2008). Bonemarrow-derived microglia: myth or reality? Curr. Opin. Pharmacol. 8, 508-518.

Stalder, A. K., Ermini, F., Bondolfi, L., Krenger, W., Burbach, G. J., Deller, T., et al. (2005). Invasion of hematopoietic cells into the brain of amyloid precursor protein transgenic mice. J. Neurosci. 25 11125-11132.

Steinerman, J. R., Irizarry, M., Scarmeas, N., Raju, S., Brandt, J., Albert, M., et al. (2008). Distinct pools of beta-amyloid in Alzheimer disease-affected brain: a clinicopathologic study. Arch. Neurol. 65 906-912.

Tagliani, E., Shi, C., Nancy, P., Tay, C. S., Pamer, E. G., and Erlebacher, A. (2011). Coordinate regulation of tissue macrophage and dendritic cell population dynamics by CSF-1. J. Exp. Med. 208, 1901-1916.

Tang, Y. P., Shimizu, E., Dube, G. R., Rampon, C., Kerchner, G. A., Zhuo, M., et al. (1999). Genetic enhancement of learning and memory in mice. Nature 401, 63-69.

Tapia-Arancibia, L., Aliaga, E., Silhol, M., and Arancibia, S. (2008). New insights into brain BDNF function in normal aging and Alzheimer disease. Brain Res. Rev. 59, 201-220.

Town, T., Laouar, Y., Pittenger, C. Mori, T., Szekely, C. A., Tan, J., et al. (2008). Blocking TGF-betaSmad2/3 innate immune signaling mitigates Alzheimer-like pathology. Nat. Med. 14, 681-687.

Tsai, K. J., Tsai, Y. C., and Shen, C. K. (2007). G-CSF rescues the memory impairment of animal models of Alzheimer's disease. J. Exp. Med. 204, 1273-1280.

Volmar, C. H., Ait-Ghezala, G. Frieling, J., Paris, D., and Mullan, M. J. (2008). The granulocyte macrophage colony stimulating factor (GM-CSF) regulates amyloid beta (Abeta) production. Cytokine 42, 336-344.

Wang, D. C., Chen, S. S., Lee, Y. C., and Chen, T. J. (2006). Amyloid-beta at sublethal level impairs BDNFinduced arc expression in cortical neurons. Neurosci. Lett. 398, 78-82.

Wegenast-Braun, B. M., Fulgencio Maisch, A., Eicke, D., Radde, R., Herzig, M. C., Staufenbiel, M., et al. (2009). Independent effects of intra- and extracellular Abeta on learning-related gene expression. Am. J. Pathol. 175, 271-282.

Xiao, B., Tu, J. C., Petralia, R. S., Yuan, J. P., Doan, A., Breder, C. D., et al. (1998). Homer regulates the association of group 1 metabotropic glutamate receptors with multivalent complexes of homer-related, synaptic proteins. Neuron 21, 707-716.

Yin, Y., Edelman, G. M., and Vanderklish, P. W. (2002). The brain-derived neurotrophic factor enhances synthesis of Arc in synaptoneurosomes. Proc. Natl. Acad. Sci. U.S.A. 99, 2368-2373.

Yoshii, A., Murata, Y., Kim, J., Zhang, C., Shokat, K. M., and ConstantinePaton, M. (2011). TrkB and protein kinase Mzeta regulate synaptic localization of PSD-95 in developing cortex. J. Neurosci. 31, 11894-11904.

Conflict of Interest Statement: The authors declare that the research was conducted in the absence of any commercial or financial relationships that could be construed as a potential conflict of interest.

Received: 30 August 2012; paper pending published: 19 September 2012; accepted: 16 October 2012; published online: 01 November 2012.

Citation: Naert G and Rivest S (2012) Age-related changes in synaptic markers and monocyte subsets link the cognitive decline of $A P P_{\text {Swe }} / P S 1$ mice. Front. Cell. Neurosci. 6:51. doi: 10.3389/fncel. 2012.00051

Copyright (c) 2012 Naert and Rivest. This is an open-access article distributed under the terms of the Creative Commons Attribution License, which permits use, distribution and reproduction in other forums, provided the original authors and source are credited and subject to any copyright notices concerning any third-party graphics etc. 